\title{
Competencies: requirements and acquisition
}

Citation for published version (APA):

Kuenn, A. C., Meng, C. M., Peters, Z., \& Verhagen, A. M. C. (2013). Competencies: requirements and acquisition. ROA. ROA Reports No. 006 https://doi.org/10.26481/umarep.2013006

Document status and date:

Published: 01/01/2013

DOI:

10.26481/umarep.2013006

Document Version:

Publisher's PDF, also known as Version of record

\section{Please check the document version of this publication:}

- A submitted manuscript is the version of the article upon submission and before peer-review. There can be important differences between the submitted version and the official published version of record.

People interested in the research are advised to contact the author for the final version of the publication, or visit the DOI to the publisher's website.

- The final author version and the galley proof are versions of the publication after peer review.

- The final published version features the final layout of the paper including the volume, issue and page numbers.

Link to publication

\footnotetext{
General rights rights.

- You may freely distribute the URL identifying the publication in the public portal. please follow below link for the End User Agreement:

www.umlib.nl/taverne-license

Take down policy

If you believe that this document breaches copyright please contact us at:

repository@maastrichtuniversity.nl

providing details and we will investigate your claim.
}

Copyright and moral rights for the publications made accessible in the public portal are retained by the authors and/or other copyright owners and it is a condition of accessing publications that users recognise and abide by the legal requirements associated with these

- Users may download and print one copy of any publication from the public portal for the purpose of private study or research.

- You may not further distribute the material or use it for any profit-making activity or commercial gain

If the publication is distributed under the terms of Article $25 \mathrm{fa}$ of the Dutch Copyright Act, indicated by the "Taverne" license above, 


\section{Competencies:}

\section{Requirements and acquisition}

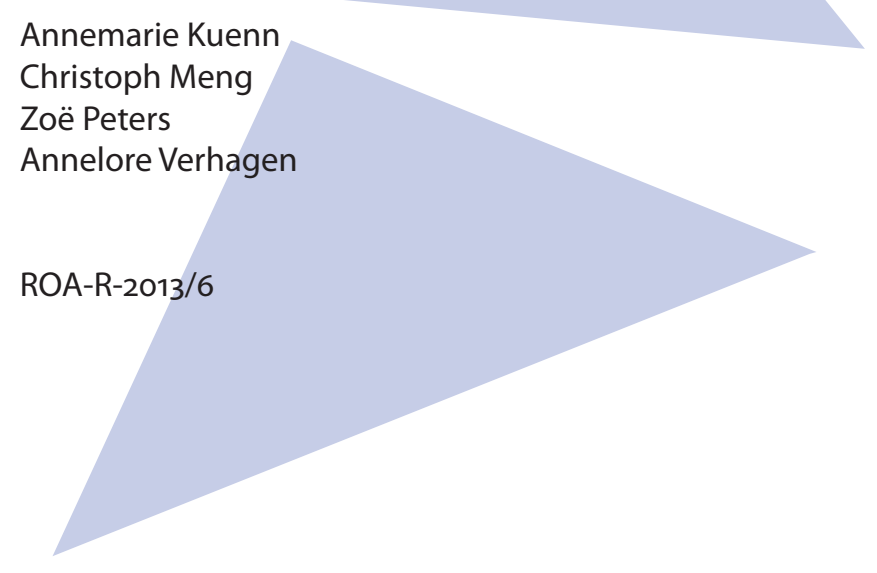




\section{Colophon}

(C) Research Centre for Education and the Labour Market (ROA). No part of this publication may be reproduced without the prior permission in writing of the director of the Research Centre for Education and the Labour Market.

\section{Research Centre for Education and the Labour Market}

School of Business and Economics

Maastricht University

\section{Layout}

Secretary ROA, Maastricht

\section{Sales}

Research Centre for Education and the Labour Market email: secretary-roa-sbe@maastrichtuniversity.nl website: www.roa.nl

ISBN: 978-90-532I-5II-I

May 2013 


\section{Contents}

1 Introduction 1

2 Competencies: acquisition, role and value 5

3 Maastricht University Scanner 9

3.1 Data 9

3.2 Labour market of Maastricht University graduates 11

4 Competencies: requirements and acquisition $\quad 15$

$\begin{array}{lll}4.1 & \text { Maastricht University } & 15\end{array}$

4.2 Comparing labour market competencies across faculties 19

$\begin{array}{ll}4.3 & \text { Labour market competencies by faculty } \\ & 22\end{array}$

4.3.1 School of Business and Economics $\quad 22$

4.3.2 Faculty of Arts and Social Sciences 26

4.3.3 Faculty of Psychology and Neuroscience $\quad 30$

4.3.4 Faculty of Law 34

4.3.5 Faculty of Health, Medicine and Life Sciences 38

$\begin{array}{ll}\text { References } & 47\end{array}$ 



\section{Introduction}

Higher education is given the key task to prepare the highly talented among the young to fulfil highly qualified roles in the labour market. Successful labour market performance of graduates is generally associated with the acquisition of the correct competencies. Education as an individual investment in human capital is a viewpoint dating back to the I7th century and the writings of Sir William Petty (I662), and includes later work by Adam Smith (I776). The idea was formalized and brought into mainstream economics by Schultz (196I), Becker (1964) and Mincer (I970, I974). The strong supply-side orientation of the human capital theory's determination of labour productivity has also raised serious doubts. One of the first major competitors of the human capital theory was the job competition model (Thurow, 1975), in its most extreme form explaining productivity entirely by occupational characteristics. Both the human capital theory and the job competition model in their original versions seem to be too restricted to one side of the labour market. More recently, therefore, approaches that allow explicitly for an interaction between supply-side and demand-side characteristics ('assignment models') have been placed centrally in analyses of education-to-work stages. For a good overview of different assignment models and their distinctive features with respect to matching models, such as proposed by Mortensen (1986), or search theories (e.g. Jovanovic, 1979), see Dupuy (2004).

In all models, to grasp the benefits of education, it is of crucial importance for individuals to understand and recognize the rapidly changing opportunities and to acquire and maintain the related competencies. Although higher education is a central place for the acquisition of competencies, such as discipline-specific or higherorder thinking skills (see Meng, 2006), there is a strong indication that not all types of relevant competencies are as effectively taught in a classroom. Innovative or entrepreneurial skills, relating to the growing need of higher education graduates to be properly prepared for management positions in a post-industrial economy, are examples. McCall, Lombardo and Morrison (1998) found that most of the development of management competencies takes place on the job, and not in seminars, classrooms or MBA programmes. A similar result was found by Heijke, Meng and Ramaekers (2003). ${ }^{\mathrm{I}}$

I. Heijke, Meng and Ramaekers (2003) show that the level of management competencies that higher education graduates need to handle in their first three years on the labour market, is more strongly related to the level of generic competencies (such as learning abilities) acquired in higher education than to the level of management competencies the graduates possess at the time of graduation. 
What does it mean to talk about competencies in the light of a knowledge-intensive economy? And more precisely, what types of competencies are crucial for higher education students to acquire? Given that the term 'knowledge economy' is a widely used metaphor rather than a clear concept, it is not surprising to find different conceptions of what the knowledge requirements are for graduates. In the early nineties, an interesting approach was provided by Lundvall and Johnson (1994). These authors distinguish between know-what, know-why, know-how and know-who. Know-what refers to factual knowledge that is easily stored and transferred. Know-why refers to scientific understanding and the impact of science on mankind. Know-how is the capability of performing certain tasks, while know-who refers to knowing the people who possess the other three knows. Implicit in this classification is the often recurring distinction between 'codified' and 'tacit' knowledge. The former can be expressed in language or symbols and is easily stored. The latter is linked directly to its bearer and is, as such, not readily transferable. It is the stock of knowledge that enables a person to select, interpret and develop codified knowledge (Eurydice, 2002).

\title{
Textbox 1.1
}

Nomenclature

\begin{abstract}
Although nomenclature may not matter very much when everybody agrees on what is meant, in the context of this report, it is pivotal to start our discussion on competencies with the question ' what is in a word'. This holds in particular for the term 'competency' as it has undergone significant changes in meaning and there has been a tendency to widen the use of the term, to include personal attributes (see e.g. Payne, 2000). These changes in definition and meaning are partly the result of the fact that the term is being used as a relevant concept by a number of research fields, each with its own disciplinary roots, and partly the result of the usage of the concept inside a research field, as either interchangeable with terms such as'skills' or as a separate concept.
\end{abstract}

Weinert (2001) gives a comprehensive state-of-the-art overview of the competency concept in different research areas. He argues that the meta-view reveals that the term 'competency' is used in all disciplines to indicate a specialized system of individual and/or collective abilities, proficiencies or skills necessary to reach a particular goal. The distinction that he makes between the terms 'skill' and 'competency' was adopted later by Rychen and Salganik (2003). Although Rychen and Salganik admit that the term 'skill' is occasionally used in a way similar or even identical to the notion of 'competency', in most cases it carries a meaning that is, strictly speaking, different from the competency connotation. 'Skill' labels an ability to perform complex motor and/or cognitive acts with ease, precision, and adaptability to changing conditions. The term 'competency' is used to designate a complex action system encompassing cognitive skills, attitudes and other non-cognitive components. Along this holistic perspective, the term 'competency' assumes that a range of mental prerequisites must be mobilized (Rychen and Salganik, 2003). In our paper, we follow the approach of the above authors and distinguish between the term 'competency' and the term 'skill'. More specifically, the term 'competency' is reserved for a group of skills, referring to a single underlying dimension and forming the condition for fulfilling complex and varying tasks inside and outside the working sphere. In this sense, the ability to heat up the oven, the ability to cut the meat, and the ability to name different herbs are regarded as skills, whereas their combined knowledge is what makes a cook competent.

In terms of educational outcomes, codified knowledge generally reflects the disciplinespecific competencies of the study field graduated from, while tacit knowledge may also refer to generic competencies that are not content-bound. As the name suggests, 
the term 'discipline-specific competencies' refers to cognitive prerequisites that an individual requires in order to perform properly in a given substantive area (Weinert, 200I). The term 'generic' is used as a label covering a diversity of concepts (for an extended overview, see for example Meng, 2006). Reviewing the literature on generic competencies reveals that neither is there a definitive list of generic competencies, nor is the term 'generic' used globally. While in some countries generic competencies are specifically seen as employment-related, in other countries the emphasis is placed more on their social relevance. Table I.I provides a brief overview of some of the terms used to indicate generic competencies in various countries.

Table 1.1

Terms used in various countries to describe generic competencies

\begin{tabular}{|l|l|}
\hline Country & Term used \\
\hline United Kingdom & Core, Key, Common \\
\hline New Zealand & Essential \\
\hline Australia & Key, Employability, Generic \\
\hline Canada & Employability \\
\hline United States & Basic, Necessary, Workplace know-how \\
\hline Singapore & Critical enabling \\
\hline France & Transferable \\
\hline Germany & Key \\
\hline Switzerland & Trans-disciplinary goals \\
\hline Denmark & Process-independent qualifications \\
\hline
\end{tabular}

Source: Australian National Training Authority, 2003

Common to all the terms referred to in Table I.I is that they are used to indicate the subject, discipline or occupation independence of the competencies considered. In this sense, generic competencies are regarded as transversal. The term 'transversal' does not refer to elements common to different subject-based competencies, but strictly to the additional, subject-independent content of these competencies that is useable in other fields (Rey, I996). Table I.2 provides an overview of common elements in various listings of generic competencies in international literature.

Table 1.2

Common elements of various listings of generic competencies

\begin{tabular}{|c|c|}
\hline Element & Examples \\
\hline Basic/fundamental skills & Literacy, using numbers, using technology \\
\hline People-related skills & Communication, interpersonal, teamwork, customer service skills \\
\hline Personal skills and attributes & $\begin{array}{l}\text { Being responsible, resourceful, flexible, able to manage one's own time, having } \\
\text { self-esteem }\end{array}$ \\
\hline Skills related to the business world & Innovation, entrepreneurial skills \\
\hline Skills related to the community & Civic or citizenship knowledge and skills \\
\hline Conceptual/thinking skills & $\begin{array}{l}\text { Collecting and organizing information, problem-solving, planning and } \\
\text { organizing, learning-to-learn, thinking innovatively and creatively, system } \\
\text { thinking }\end{array}$ \\
\hline
\end{tabular}

Source: Australian National Training Authority, 2003 
We need to keep in mind that our focus in this report is on higher education and hence on higher-order thinking skills rather than on lower-order ones, as distinguished in Bloom's taxonomy of educational objectives (Bloom 1956). In this sense, we are interested in aspects that can be regarded as crucial elements of the generic competency package that higher education graduates take with them when they enter the labour market and that can be taught in higher education. Based on that, the sixth element - 'conceptual/thinking skills'- seems to be most promising one. It includes items such as 'collecting and organizing information', 'problem-solving' but also 'learning to learn'. Meng (2006) refers to conceptual/thinking skills as 'academic competencies' and links them strongly to 'meta-cognitive competencies' on the one hand and the concept of 'critical thinking' on the other. Meta-cognitive competencies relate to the expertise about oneself as a knower, learner and actor (Weinert, 200I). Ennis (1987) defined critical thinking as 'reasonable reflective thinking that is focused on deciding what to believe or do.' It involves 'formulating hypotheses, alternative ways of viewing a problem, questions, possible solutions, and plans for investigating something' (Halpern, 1998). Its distinction from lower-order thinking skills with their main focus on knowledge, comprehension and/or application, thus follows the aforementioned taxonomy of education objectives as given by Bloom (1956). Items belonging to the element of critical thinking/academic competencies in this sense are inherent parts of higher education programs and make them of particular interest for our report, which tries to address the following questions: What are the competency requirements that graduates of Maastricht University are confronted with on the labour market? Given the strong international orientation of Maastricht University, are there differences in labour market requirements in the Netherlands compared to other countries? To what extent are such competencies acquired during the university study and to what extent afterwards, during the first years on the labour market? What are the strengths and weaknesses of Maastricht University in terms of competency acquisition?

The setup of the report is as follows: Section 2 discusses some recent research on the acquisition and role of competencies. Section 3 briefly discusses the source of the data used for this report and provides insight in the labour market of Maastricht University graduates. The proof of the pudding, namely the eating, is presented in Section 4, in which we discuss the competency requirements, the acquisition of competencies and strengths and weaknesses of the study at Maastricht University level. Section 4 also compares faculties and discusses these points in more detail for the individual faculties. 


\section{Competencies: acquisition, role and value}

In recent years, higher education has faced to an ever larger degree an increased demand for higher-order thinking competencies. They provide graduates with abilities that are not only useful in addressing problems in a creative manner, but can also be used to expand and adapt the potentialities of an existing job. In this line, Sternberg (2003) proposes that the future needs a "generation of experts, whose expertise will extend well beyond technical knowledge" and hence experts that possess competencies that enable them to use the technical knowledge. The tension between the demand for disciplinespecific specialists with their high direct productivity, and the 'active agents' with their (long-term) flexibility is not new to economic literature. In fact, it relates to the question of specialist vs. generalist that dates back to pre-industrialization literature. Whereas Adam Smith (I776), addressing the division of labour stated:

"The greatest improvement in the productive powers of labour, and the greater part of the skill, dexterity, and judgment with which it is any where directed, or applied, seem to have been the effects of the division of labour" (Smith, I776).

Say (I8O2) warned that such specialization often goes hand in hand with inflexibility:

"A man, whose whole life is devoted to the execution of a single operation, will most assuredly acquire the faculty of executing it better and quicker than others; but he will, at the same time, be rendered less fit for every other occupation, corporeal or intellectual... "(Say, I802).

Research on the market value of particular types of competencies, allowing for a differentiation in the returns to education, however, started only recently. Noteworthy studies include Green (1998), Heijke, Koeslag and Van der Velden (1998), Allen and Van der Velden (200I), Green, Ashton and Felstead (200I), McIntosh and Vignoles (200I), Shaughnessy, Levine and Cappelli (200I), Stasz (200I), Ter Weel (2002), Lazaear (2003), Heijke, Meng and Ramaekers (2003), Heijke, Meng and Ris (2003), Heijke, Ramaekers and Ris (2005), and Meng (2006). In particular the more recent of these studies indicate that both discipline-specific competencies and generic competencies in general, and academic competencies in particular, play an independent strategic role for graduates in their efforts to obtain a position in the labour market. 
The studies show that discipline-specific competencies provide graduates with a comparative advantage in their performance of jobs in the professional domain of their own study programme. In line with this, graduates with a high level of discipline-specific competencies more likely find jobs in their own professional domain and profit in this sense from higher wages than graduates who start their working careers outside their own professional domain.

Graduates with a high level of generic competencies in general and academic competencies in particular, on the other hand, are more likely to start their working careers outside their own professional domain where the discipline-specific knowledge acquired during their study is less useful, wages are relatively lower and where graduates have to be able to adapt quickly to new conditions. This is where the generic (academic) competencies are helpful. Academic competencies are a necessary condition for graduates to react to such required adaptation due to a 'mismatched' allocation. Next, they also enable the graduates in more general ways to react to changes that take place in the labour market as a result of, for example, technological changes, as well as the related changes in the way organizations are managed. ${ }^{2}$ They determine the graduates' adjustment potential, make them more inclined to take part in training activities that allow them to quickly reduce any competency deficiencies and make them more capable of acquiring the required competencies to obtain supervisory positions. Both types of efforts yield a wage increase, which means that generic competencies in general and academic competencies in particular pay off in time in a more indirect way.

So far, we have considered the role of competencies acquired in higher education without taking into account that different labour markets may require different mixes of competencies. A simple, but in this sense crucial, distinction is the one that distinguishes between internal labour markets (ILM) and occupational labour markets (OLM). The distinction between these two types of labour markets is generally seen in the institutional rules of access to skilled workers' positions, which are defined as positions requiring task-specific competencies. Educational credentials, such as the field of study, provide little guidance in the allocation of individuals to occupations in case of ILMs, as they lack occupational specificity. Graduates start at entry port occupations and are trained in firm-specific competencies allowing mobility into higher positions. In contrast, in OLMs there is a strong link between discipline-specific competencies acquired in education and the ones asked by employers. Even though occupational and internal labour markets may coexist in a country, the relative weight between the two institutional arrangements varies strongly between countries (see e.g.

2. Related to this argument is the fact that an increased uncertainty with which discipline-specific competencies can be applied in a constantly changing labour market, requires from graduates that they are able to continue learning and/or to acquire new or different types of competencies after graduating from higher education. Investment in academic competencies during higher education provides in this sense an option to be cashed in in case the discipline-specific competencies are of reduced value later on. 
Eyraud, Marsden and Sylvestre, I990). Along this line, Gangl (200I) used Marsden's criteria (see Marsden, 1990) to divide European countries into OLM and IML countries. Typical representatives of ILM countries are the United Kingdom and France. The Netherlands is a representative of an OLM country, just like Germany and Austria. Meng (2006) not only shows that the competencies required in the labour market/acquired in higher education are - in relative terms - in line with this distinction (e.g. Dutch higher education graduates are more discipline-specifically oriented than their English counterparts), but that the previously discussed role and value of competencies are context-dependent. Whereas in Germany and the Netherlands a high level of discipline-specific competencies is a benefit for finding an occupation inside one's own professional domain, this result could not be reproduced for the United Kingdom. Similar, whereas in OLM countries a lack in discipline-specific competencies reduced wage rates, in ILM countries a lack of academic competencies triggered a reduction in wage rates.

Considering our focus on the Netherlands, we also have to take into account the occupational orientation of the Dutch labour market and the possible relatively higher value attached therefore to discipline-specific competencies.

\section{Textbox 2.1}

How to successfully implement innovative learning environments? (from Allen and Van der Velden, 2012)

Over the past two decades there have been many advocates promoting the use of innovative methods for developing 21st-century skills and indeed these methods have been widely introduced in education. In the Netherlands, most - if not all - of the programs in upper secondary and tertiary education use some form of student-centred method such as self-regulated learning, problem-based learning or project-based learning, and the goals of education are defined in competencies rather than skills. The OECD Centre for Educational Research and Innovation (CERI) has made a valuable contribution to this discussion with the publication of the report 'The Nature of Learning' (OECD, 2010a), in which leading scholars advocate the development of innovative learning environments such as inquiry-based learning, collaborative learning and other student-centred modes of teaching.

There is ample evidence that these innovative learning environments indeed foster relevant 21st-century skills such as communication, cooperation and problem-solving skills.

But there are also some caveats. That is to say, innovative modes of teaching and learning can be highly effective, but only under specifically prescribed circumstances. Failing to meet these conditions may render these innovative methods less efficient or even ineffective. To give a few examples:

There is probably little doubt that cooperative learning has a positive effect on cooperation skills, but the effect on cognitive achievement is less straightforward. Group dynamics may lead to a less than desirable learning environment and there is the constant danger of free riding. Slavin (2010) points out that cooperative learning only yields positive results in achievement outcomes when two conditions are present: clearly defined group goals and individual accountability. When these conditions are not met, it is unlikely that cooperative learning will be effective. 


\section{Textbox 2.1 (continued)}

How to successfully implement innovative learning environments? (from Allen and Van der Velden, 2012)

Self-regulated learning is generally seen as an important way of developing metacognitive skills and increasing intrinsic motivation. It is therefore one of the key constituent elements of many innovative learning environments (e.g. the Dutch educational reform in secondary education, the "Studiehuis"). Recent insights from neurosciences, however, shed some doubt on whether self-regulated learning is always possible (Jolles, 2007). It turns out that the adolescent's brain is not yet ripe for engaging in the long-term planning that is necessary for effective selfregulation. This applies more to boys than to girls, which is probably one of the reasons why boys have profited less from the introduction of self-regulated learning in the "Studiehuis" than girls, as was shown by a recent evaluation by Coenen, Meng and Van der Velden (2011). It is crucial to take these and similar insights into account, in order to specify the conditions under which self-regulated learning is likely to be effective.

- There is strong evidence that inquiry-based learning approaches such as project-based and problem-based learning develop academic skills. Students learn more deeply when they can apply classroom-based knowledge to real-world problems, all the while nurturing 21st-century skills such as communication, cooperation and creativity. However, it is less evident that this is always the most effective way to develop specific skills. To develop a body of knowledge in a given domain, students need structure. This structure enables them to see how new information fits within their existing frame of reference. In a traditional classroom setting, this structure is usually provided by the teacher who acts as an expert, or by the classical textbook. This structure helps students get a good overview of the whole body of knowledge to be learnt. Meng (2006) has shown that in a situation where the role of teachers is limited to supervising the process rather than serving as an important source of information, the development of domain-specific skills lags behind.

- And finally, an excessive focus on innovative methods may easily obscure the fact that effective skills acquisition also requires practice, repetition and routine. Although we take this for granted in the case of skill acquisition in sports or music, it seems that for other skill domains this has become something old-fashioned and outmoded. But there is no reason to assume that acquiring expertise in whatever domain can do without some form of practice and repetition.

The list can easily be expanded. The main message is that the success of innovative learning methods is crucially dependent on the conditions under which they are implemented. The knowledge about which conditions are crucial is unfortunately less well developed and also less widespread than the methods themselves. Many of the technologies listed above in relation to assessment (Beller, 2011) are potentially relevant to the implementation of innovative learning environments, and can, if used appropriately, help solve some of the problems related to their implementation. Once again however, this requires a teaching staff who know how to deal with the technologies in question. 


\section{Maastricht University Scanner}

\subsection{Data}

Since the beginning of the nineties, Maastricht University has followed its graduates by means of questionnaires I, 5 years, 6 years and II years after graduation. The core questions of the surveys focus on the labour market situation of these graduates, on the link between the labour market situation and the study completed at Maastricht University, and on the quality of their studies in the eyes of the graduates. In 20 Io and 20II, the questionnaires among the graduates who left Maastricht University 6 and II years earlier asked them to provide information on a set of 16 individual skills.

Table 3.1

\begin{tabular}{|l|l|}
\hline Cluster & Original item \\
\hline Academic competencies & Communication skills \\
\hline & Ability to make clear to others what you mean \\
\hline & Ability to cooperate productively with others \\
\hline Ability to bear responsibility \\
\hline Professional expertise & Ability to work accurately \\
\hline Confidence & Ability to analyze and solve problems \\
\hline & Knowledge about your own field or discipline \\
\hline ICT competencies & Ability to apply your professional knowledge \\
\hline Running meetings & Ability to cope with uncertainty \\
\hline Cultural aspects & Ability to assess one's own abilities and those of others \\
\hline Legal aspects & Ability to accept criticism \\
\hline Other discipline knowledge & Ability to use information- \& communication technology \\
\hline
\end{tabular}

The UM Scanner uses a direct and subjective approach to measure the knowledge and skills required in the labour market. More precisely, the graduates are asked to indicate on a five-point Likert scale, ranging from I ('not at all') to 5 ('to a very high extent') the extent to what a particular item is required in their current work. Handling all the 
individual items provided by the data set separately not only hampers a clear interpretation of results but also ignores the fact that individual items may be closely related and that their value as a group is larger than the sum of individual items. The latter argument is in line with our proposition that the term 'competency' should be used to designate a complex action and not an individual ability. Accordingly, we shall use sets of skills that belong together and refer to one dimension. To do so, we approached the individual skills items measured in the UM Scanner by means of cluster analyses (for a more detailed discussion of the approach used here, see Meng, 2006). Cluster analyses allow the large group of items to be divided into smaller ones, where items within a group are similar in nature, and observation in different groups is relative dissimilar in nature (see e.g. Latin, Carroll, Green, 2003). On the basis of the cluster analyses, II individual items can be grouped in three clusters of competencies. The remaining 5 items will be treated individually. Table 3.I shows the three clusters and indicates which individual items are grouped together.

The main attractiveness of the self-assessment method used here to measure the level of competencies required in work, lies in the fact that graduates may be the ones who know best what is required in the jobs they have. The main disadvantage is related to the significant possibility of measurement errors. First, by asking graduates to judge the work they do, one naturally risks getting answers biased towards pompousness or exaggerated modesty. Second, one needs to deal with a potential error related to vagueness and/or ambiguity in the question. This may lead to systematic errors due to the fact that certain graduates interpret an item differently than others. Moreover we have to deal with the possibility that different graduates (e.g. graduates from different disciplines) use different 'yardsticks' when they answer the questions.

What we need to do next - and this holds in particular for the individual items grouped into the three clusters of competencies - is to have a closer look at the validity of the construct as groups of individual skills required in the current job.

The most basic form of validity is the content validity. To address it, one needs to critically examine the measure of the concept in the light of the intended meaning. Taking a first look at the three clusters under consideration, we can state that they seem to represent rather well what was intended. There is no doubt that the combination of knowledge about your own field or discipline and ability to apply your professional knowledge constitutes the core of discipline-specific knowledge of one's own field of study. Interestingly, the ability to apply professional knowledge correlates much stronger with the level of knowledge of one's own field or discipline than with the level of knowledge of other fields of study. We will have to keep that in mind when we discuss our analyses, as in this sense the construct own discipline-specific knowledge will differ in a crucial element from the construct other discipline-specific knowledge. Secondly, aspects such as communication skills, the ability to cooperate productively with others, or the ability to analyze and solve problems are certainly relevant components of what we called earlier academic or higher-order thinking skills. Finally, items 
such as the ability to cope with uncertainty or the ability to accept criticism seem to cover rather well the term 'confidence'.

A second check that is closely related to the first one, is to examine the internal consistency of the data constructs. To test it, Cronbach alphas are calculated for the three clusters of items, indicating how well a set of items measures a single one-dimensional construct. Generally spoken, alphas of 0.9 and larger are considered to indicate a very good level of scale reliability, whereas values of 0.7 or more are generally regarded as acceptable (Nunnually, 1978). The first two clusters, academic competencies (Cronbach alpha: 0.75 ) and professional expertise (0.72), pass this second test. The third cluster (confidence) shows a lower scale reliability (o.63). However, further analyses show that the internal consistency measured by the Cronbach alpha is not improved by leaving aspects out of the cluster. Therefore, we will continue to work with all three clusters, keeping in mind that the internal consistency is weakest for the cluster 'confidence'.

In addition to the question about the required level of competencies in their current jobs, the graduates were asked to answer two more questions with respect to these competencies. Firstly, they were asked to indicate on the one hand a maximum of three competencies from the list which they believed to be strengths and on the other hand a maximum of three competencies which they believed to be weaknesses of the study they had completed at Maastricht University. Secondly, the graduates were asked to indicate for each individual item the percentage of current knowledge they had acquired at Maastricht University and which percentage they had acquired after graduation.

\subsection{Labour market of Maastricht University graduates ${ }^{3}$}

The match between the graduates' education and the requirements of their jobs has important implications for the extent to which graduates can use their knowledge and skills. Moreover, the quality of the match between education and job is generally positively related to job satisfaction, career opportunities and wages. With respect to the match, we can distinguish two dimensions, namely the vertical match (i.e. whether graduates are working in a job for which a university degree is required) and the horizontal match (i.e. whether graduates are working in a job for which their (or a closely related) field of study is required). Tables 3.2 and 3.3 provide further information with respect to these two dimensions for the two cohorts of Maastricht University graduates (2000-200I and 2005-2006) that were interviewed in 2012.

3. For more detailed information on the labour market of Maastricht University graduates, please refer to the yearly reports and factsheets published by the Research Centre for Education and the Labour Market (www.roa.nl). 
Table 3.2

Vertical Match (\%)

\begin{tabular}{|l|r|r|}
\hline & $2000-2001$ cohort & $2005-2006$ cohort \\
\hline Business and Economics & 88 & 85 \\
\hline Health, Medicine and Life Sciences & 90 & 81 \\
\hline Arts and Social Sciences & $X$ & 85 \\
\hline Psychology and Neuroscience & 88 & 91 \\
\hline Law & 94 & 94 \\
\hline Maastricht University & 89 & 85 \\
\hline
\end{tabular}

In 20I2, hence 6 years after graduation (for the 2005-2006 cohort), 85\% of the Maastricht University graduates work in a job that requires at least a university degree. For those who graduated in 2000-200I, the percentage is as high as $89 \%$. Even though there are slight differences between the faculties, we can conclude that Maastricht University in its first 6 to II years on the labour market is generally able to position them in jobs that are on a high level.

Table 3.3 presents the results with respect to the horizontal match for the cohort 20052006. We distinguish between three different matches: (I) The own domain in which graduates indicate that the employer required specifically a degree from their field of study or from a closely related field of study, (2) the other domain in which graduates indicate that the employer required a degree from a different field of study and (3) the generic domain in which graduates indicate that the employer did not require a degree from a particular field of study.

\section{Table 3.3}

Horizontal Match (\%), cohort 2005-2006

\begin{tabular}{|l|r|r|r|}
\hline & Own domain & Other domain & Generic domain \\
\hline Business and Economics & 84 & 3 & 13 \\
\hline Health, Medicine and Life Sciences & 84 & 6 & 10 \\
\hline Arts and Social Sciences & 50 & 21 & 29 \\
\hline Psychology and Neuroscience & 80 & 4 & 16 \\
\hline Law & 85 & 3 & 12 \\
\hline Maastricht University & 82 & 6 & 13 \\
\hline
\end{tabular}

In 20I2, hence 6 years after graduation, $82 \%$ of the Maastricht University graduates work in a job for which their (or a closely related) field of study is required. Of those not working in the own domain, $13 \%$-point are working in the generic domain and 6\%-point in the other domain. The Faculty of Arts and Social Sciences knows the highest percentage of graduates that work outside their own domain, with $29 \%$ of the graduates working in the generic domain and 21\% in the other domain. Even though their specific discipline knowledge might be of a slightly lower value outside the own 
domain, further analyses show that the relative broad studies provided by the Faculty of Arts and Social Sciences allow the graduates to work on a high level outside their own domain without having to bear costs in terms of salary or job satisfaction.

The last aspect to be considered briefly is the regional location of the current job. Considering the international orientation of Maastricht University and the fact that English is the main language of instruction in many study programs, it appears to be attracting an increasing number of international students for all faculties. Table 3.4 shows the percentage of Maastricht University graduates from the various cohorts who are currently working inside and outside the Netherlands, broken down by faculty. For Maastricht University as a whole, $24 \%$ of the graduates from the $2005-$ 2006 cohort work in countries other than the Netherlands. For the older cohort, this is $12 \%$. These numbers include foreign students who returned to their home countries after graduation. Table 3.4 also shows considerable variation between the faculties. In particular graduates from the School of Business and Economics are internationally active, closely followed by their colleagues from the Faculty of Psychology and Neurosciences. Graduates from the Faculty of Arts and Social Sciences and the School of Business and Economics, however, stand out most notably. Of the 20052006 cohort, $39 \%$ of these students worked in countries other than the Netherlands. We will return to the question of the international labour market later in this report, when we discuss the question if competency requirements are similar inside the Netherlands and abroad.

Table 3.4

Currently abroad (\%)

\begin{tabular}{|l|r|r|}
\hline & $2000-2001$ cohort & $2005-2006$ cohort \\
\hline Business and Economics & 24 & 39 \\
\hline Health, Medicine and Life Sciences & 6 & 5 \\
\hline Arts and Social Sciences & $X$ & 39 \\
\hline Psychology and Neuroscience & 4 & 20 \\
\hline Law & 7 & 10 \\
\hline Maastricht University & 12 & 24 \\
\hline$X=$ to few cases & & 2 \\
\hline
\end{tabular}





\section{Competencies: requirements and acquisition}

What competency requirements do graduates of Maastricht University face and what do they see as strengths and weaknesses of their study programmes at Maastricht University? These and other questions are addressed in this section in three steps. First, we analyze the questions on a university level. Second, we provide a first comparison between the different faculties and finally, we discuss in more detail the questions for each individual faculty.

\subsection{Maastricht University}

To start with, Figure 4.I shows the percentage of graduates who indicate that a specific item is to a high or very high extent required in their current jobs. The setup of the Figure - according to our cluster approach - is presented in Table 3.I of this report. As Figure 4.I shows, it is in particular the items that belong to the cluster of academic competencies that are to a high or very high extent required in their current jobs. For more than $80 \%$ of the Maastricht University graduates these items are required to a large of very large extent in their current jobs. Although we see little variance between the 6 items when we take the two answer categories together, if we look at the answer categories individually, we find some interesting differences. The item with the highest percentage of answers in category 5 ('very high' requirement) is the ability to analyze and solve problems (54\%), followed by communication skills (49\%) and in third place the ability to make clear to others what you mean (47\%). These three items certainly belong to the core of the problem-based learning environment provided by Maastricht University, implying that Maastricht University provides its graduates with good baggage for a successful transition into the labour market.

With respect to the cluster of professional expertise, we see an interesting distinction between the two underlying items. Whereas 4 out of 5 graduates report that the knowledge about your own discipline is required to a high or very extent, the ability to apply your professional knowledge is required to a high of very extent in less than $50 \%$ of the cases. Moreover, only $26 \%$ and $4 \%$, respectively, indicate that these abilities are required on a very high level. 
Figure 4.1

Competencies requirement, Maastricht University

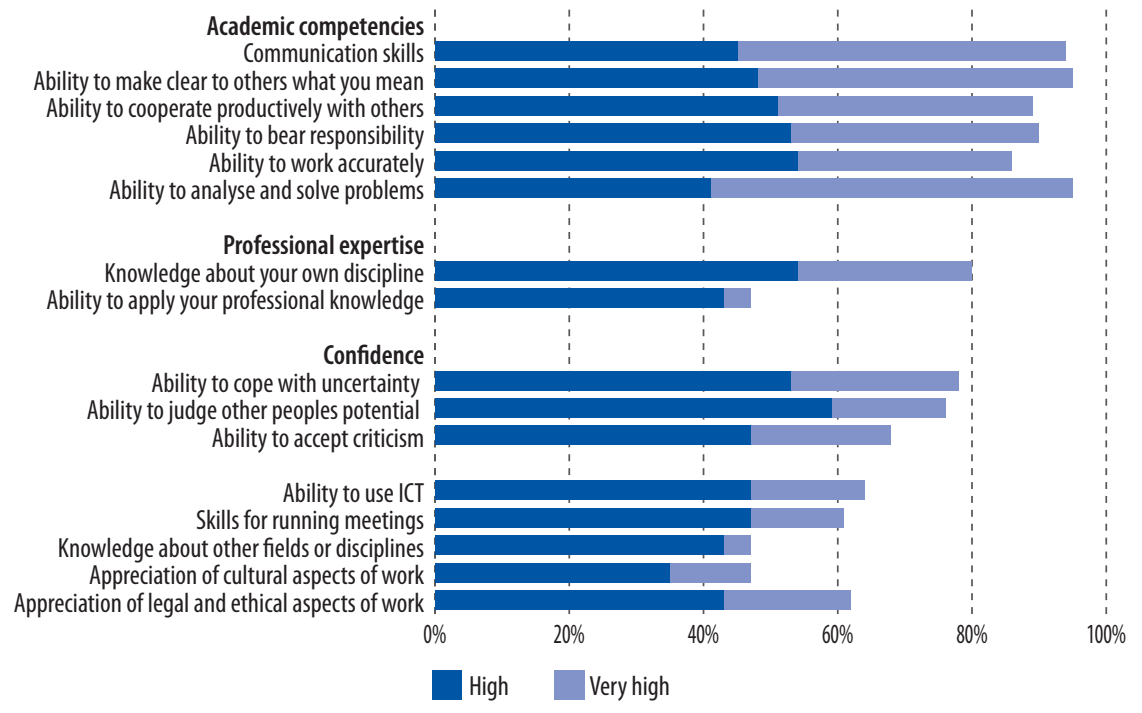

The three abilities clustered under the term confidence also seem to be required on a high level, in general. Between 68\% (ability to accept criticism) and $78 \%$ (ability to cope with uncertainty) of the graduates report a high or very high requirement of these items in their current jobs. Of the remaining items, only three are required to a high or very extent in at least 6 out of Io cases. $64 \%$ of the graduates report that the ability to use ICT is required on such a level, $62 \%$ indicate such a level for the appreciation of legal and ethical aspects and 61\% for skills for running meetings. The lowest requirements are found for knowledge about other fields or disciplines and the appreciation of cultural aspect of work. Whereas the first result is linked to the fact that most graduates work in jobs closely related to their field of study, the second result is not and, given the rather international labour market of Maastricht graduates and the importance of the international classroom given by Maastricht University, it is rather surprising. We will come back to this point when we discuss differences between graduates working in the Netherlands and graduates working abroad.

Given this brief overview over the requirements in the labour market, it is of interest to ask to what extent Maastricht University has prepared its graduates for these competencies. To analyze this question, Figure 4.2 shows for each of the distinguished items the percentage of graduates who indicate this as a strength or weakness of his or her study at Maastricht University.

The ability to analyze and solve problems is mentioned most often as a strength of Maastricht University (68\% indicate it as a strength of their study). Only $4 \%$ mentions this competency as a weakness. This is very good news for the university as this competency, as discussed above, is indicated by $95 \%$ as being required to a high or very high 
extent in the current jobs. Maastricht University also scores high on the knowledge about one's own field or discipline (in $4 \mathrm{I} \%$ of the cases mentioned as a strength) and communication skills (in $40 \%$ mentioned as a strength). Nevertheless, for these competencies the percentages of Maastricht University graduates who denote these competencies as weaknesses of Maastricht University are not negligible (24 and 16\%, respectively). This contradicting finding may be caused by the fact that graduates from all faculties were combined. We will return to this point when we differentiate across faculties later on in this section.

Figure 4.2

Strengths and weaknesses of Maastricht University

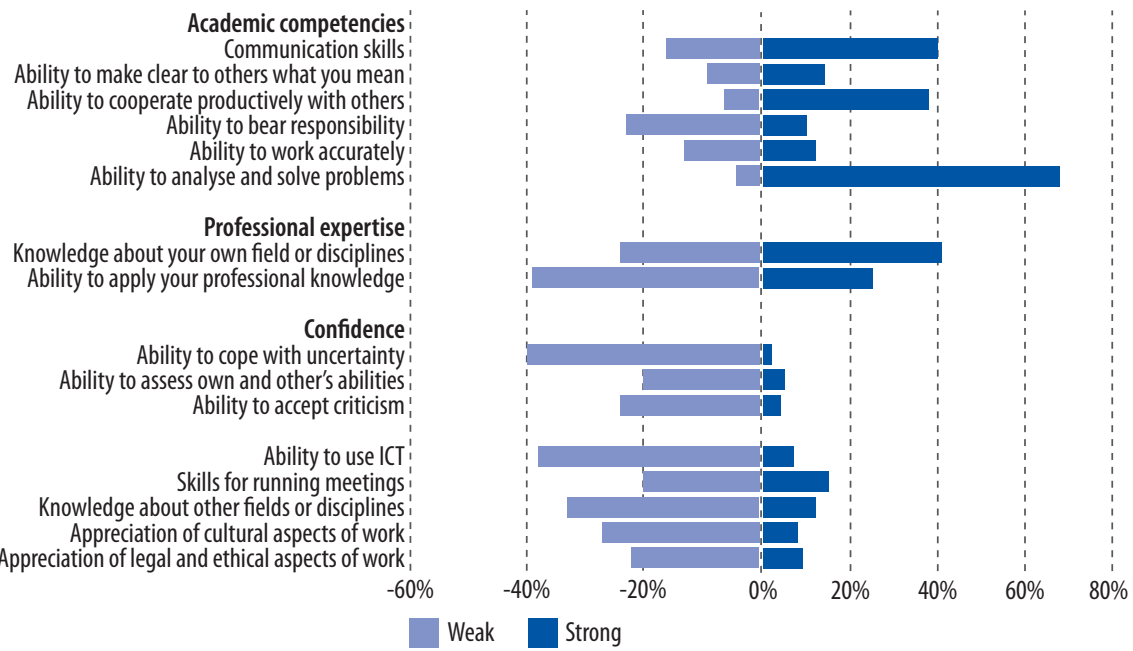

On the negative side, we find three items that score rather high. First of all, 39\% of the graduates of Maastricht University indicate that the ability to apply professional knowledge is a weakness. Also the ability to use ICT and knowledge about other fields or disciplines are often indicated as weaknesses of Maastricht University (for $38 \%$ and $33 \%$ of the graduates).

In Figure 4.3, we compare the percentage of Maastricht University graduates who report that they require certain competencies to a high or very high extent, to the net percentage of graduates who state that these competencies are strengths of the Maastricht University. We talk about the net percentage of graduates, as we subtract the percentage of graduates reporting that they experience a certain competency as a weakness from the percentage of graduates reporting that they view a certain competency as a strength. The dots in the Figure reflect the 16 competencies considered in this report. The comparison between - on the one hand - the level of required competencies and - on the other hand - the degree to which graduates mention competencies as strengths of the Maastricht University, indicate the match between 
the competencies that graduates need in the labour market and the degree to which the university provides these.

\section{Figure 4.3}

Relation between competencies required and Maastricht University strengths

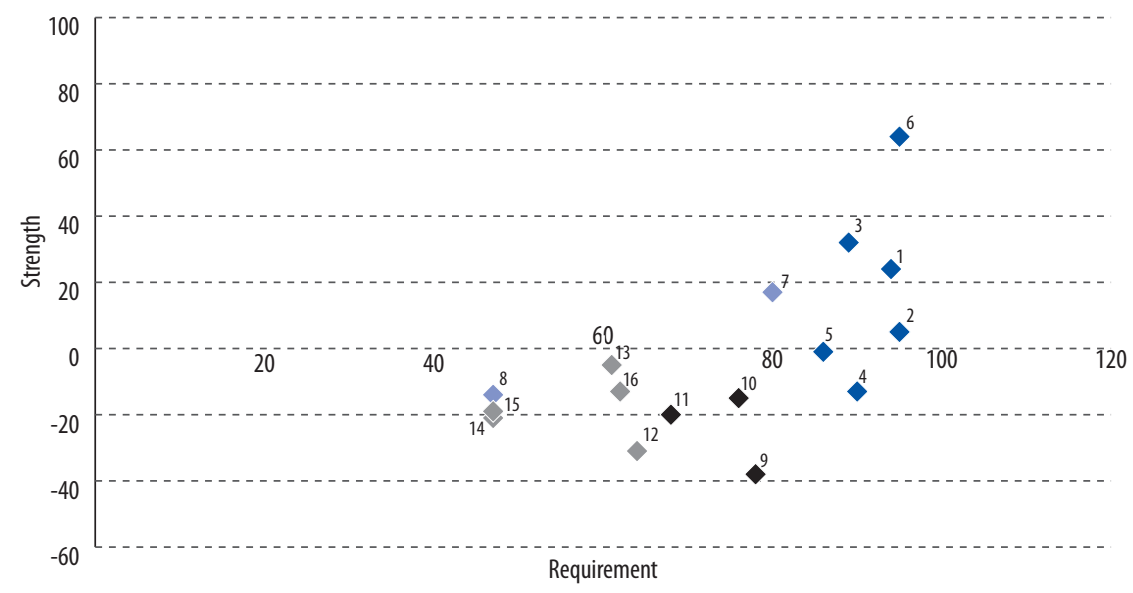

$1=$ communication skills

$3=$ ability to cooperate productively with others

$2=$ ability to make clear to others what you mean

$5=$ ability to work accurately

$4=$ ability to bear responsibility

$7=$ knowledge about your own discipline

$6=$ ability to analyse and solve problems

$8=$ ability to apply your professional knowledge

$9=$ ability to cope with uncertainty

$11=$ ability to accept criticism

$10=$ ability to judge other peoples potential

$12=$ ability to use ICT

$13=$ skills for running meetings

$14=$ knowledge about other fields or disciplines

$15=$ appreciation of cultural aspects of work

$16=$ appreciation of legal and ethical aspects of work

Figure 4.3 shows that the match between required competencies and the strength of the Maastricht University is good for most academic competencies. On average, these competencies are required to a high or very high extent by at least $85 \%$ of the graduates and at the same time more students mention these competencies as strengths instead of weaknesses of the Maastricht University. Exceptions are the ability to bear responsibility (4) and the ability to work accurately (5). Whereas the competencies with respect to confidence are required to a large or very large extent by about three out of four Maastricht University graduates, these competencies are often seen as weaknesses of the Maastricht University. The discrepancy is especially large for the ability to cope with uncertainty (9). The other competencies (I2-I6) are required to a large or very large extent by 47 to $64 \%$, whereas Maastricht University graduates see these competencies as weaknesses of the Maastricht University. Summarizing, the Maastricht University does a good job in providing the most important competencies (academic ones) but fails to sufficiently provide some other important competencies, such as the ones related to confidence and the ability to use ICT (I2). 


\subsection{Comparing labour market competencies across faculties}

In the previous section, we have seen the importance of specific competencies for the university as a whole. It is plausible that the extent to which competencies are required in the labour market is not the same across faculties. Therefore, we will first look at the different faculties. The faculties that are addressed are Business and Economics (SBE), Arts and Social Sciences (FASoS), Health, Medicine and Life Sciences (FHML), Law, and Psychology and Neuroscience (P\&N). The faculty of Humanities and Sciences is not included in this report because the number of respondents is too small.

In Figure 4.4, we observe - for each faculty separately - the set of skills grouped together as academic competencies and the extent to which these are required in the labour market. The Figure shows that academic competencies are deemed very important for the current work of graduates of all faculties. Almost every student rates these competencies as necessary for a labour market career. More than $90 \%$ of students rate communication skills, making clear what they mean and the ability to analyze and solve problems with a score of 4 or 5 (excellent). Also academic competencies such as skills of cooperating with others, bearing responsibility and working accurately are awarded with a score of 4 or higher by more than $80 \%$ of graduates across all faculties. Cooperating with others is regarded as a less important competency (but still above $80 \%$ of the cases) by law graduates.

\section{Figure 4.4}

Required academic competencies per faculty

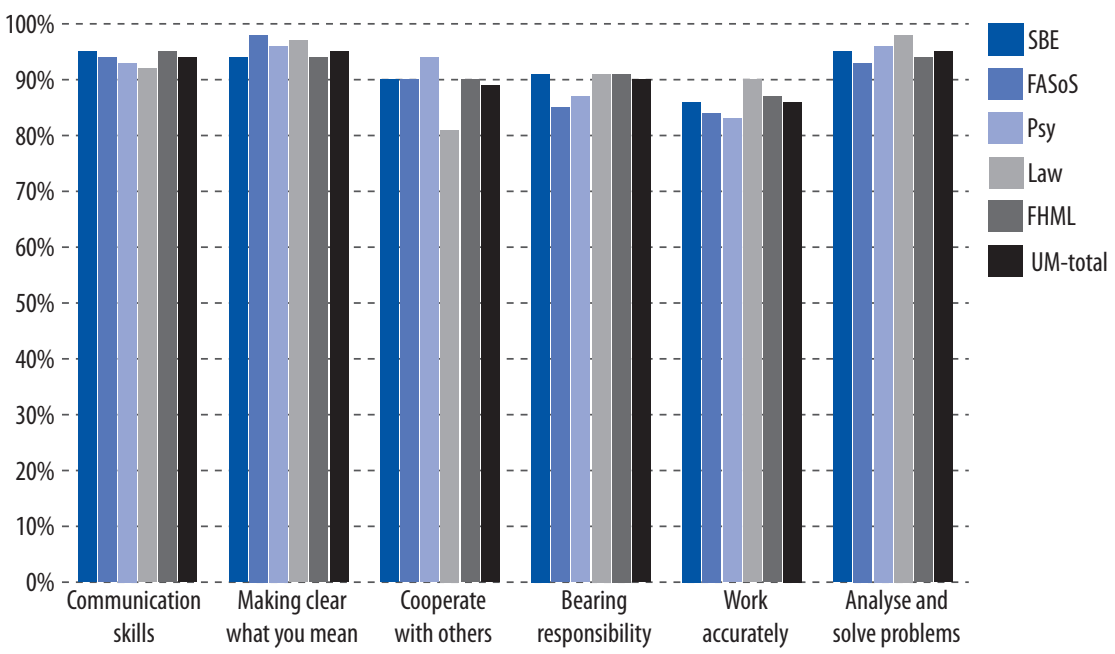

In Figure 4.5, we observe the two competencies related to professional expertise. Knowledge related to one's own discipline is a competency that graduates of all faculties indicated as being required to a high or very high extent. The percentages vary 
only slightly, from $73 \%$ among graduates from the Faculty of Arts and Social Sciences to $82 \%$ among graduates of the faculty of FHML. For graduates from all faculties, the application of professional knowledge is mentioned less often as being required to a high of very high extent for their current work. With $55 \%$ of the graduates mentioning the application of professional knowledge as being required to a high or very high extent, SBE scores highest on this required competency.

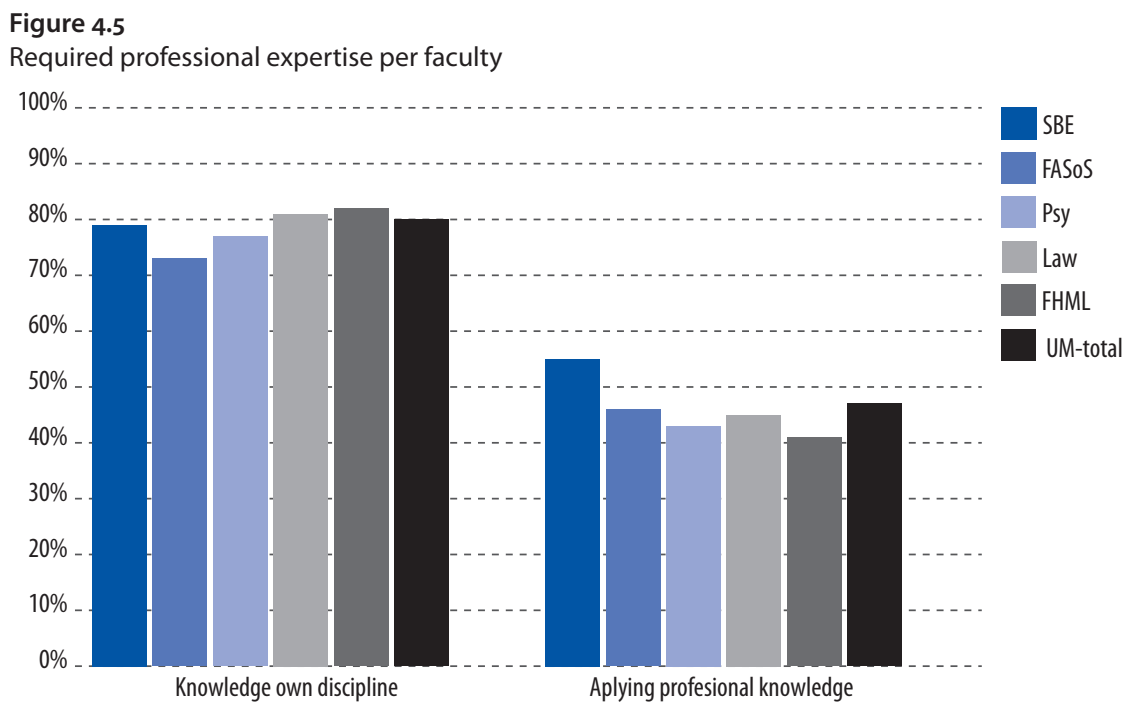

Figure 4.6 presents the percentage of graduates who denote competencies related to confidence as being highly or very highly required in their current work. The requirement of being able to cope with uncertainty in one's current work is rated very similarly among graduates from different faculties. Slightly below $80 \%$ of the graduates of all faculties denote this competency as being highly or very highly required. The ability to assess one's own and others' abilities is not equally required in jobs of Maastricht University graduates. Less than $70 \%$ of the graduates from the law faculty $(67 \%)$ report this competency as being highly or very highly required. This is $16 \%$ less than graduates from the P\&N faculty. The ability to accept criticism is mentioned most often by graduates from FASoS as being required to a high or very high extent $(80 \%)$. This competency is mentioned least often as being required to a high or very high extent by graduates from the SBE (72\%). 
Figure 4.6

Required confidence expertise per faculty

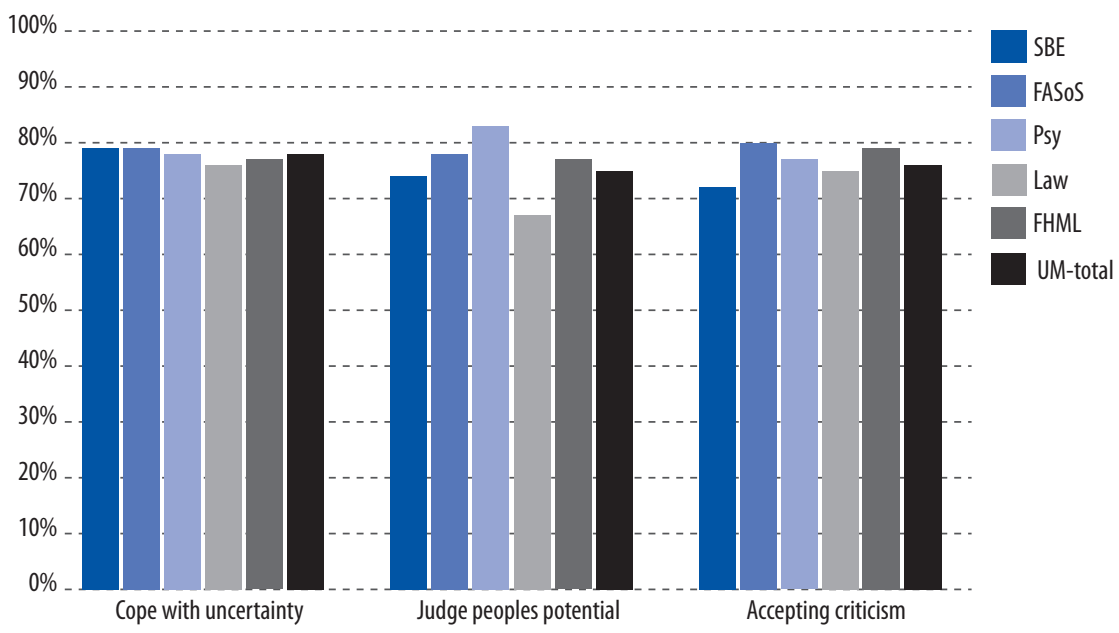

Figure 4.7

Remaining requirements per faculty

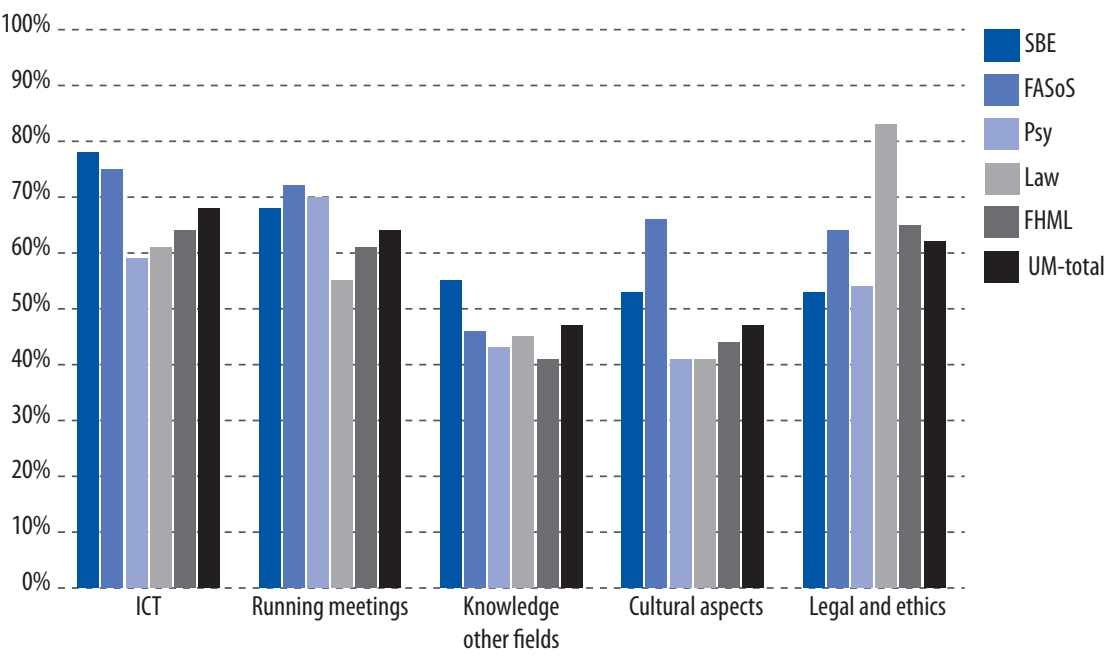

As can be seen in Figure 4.7, the need for the remaining competencies differs more across graduates from different faculties. The use of ICT competencies and knowledge about other fields or disciplines are most important among graduates from the SBE, compared to other Maastricht University faculties. Skills for running meetings and appreciation of cultural aspects of work are required most in the current jobs of graduates from FASoS. Especially the latter is not surprising due to the content of the fields of education taught in the Faculty of Arts and Social Sciences. The same holds for the 
competency "appreciation of legal and ethical aspects of work", which - as expected is required most in jobs of former law students.

\subsection{Labour market competencies by faculty}

In this section, we show more detailed information for each faculty separately. We first show the percentage of graduates who denote certain competencies as being required in their current work to a high or very high extent. Second, we show for each faculty the strengths and weaknesses as perceived by their graduates. Third, we report the percentage of skills that graduates need in their current jobs and that they acquired during their studies at Maastricht University. The themes are reported only for those graduates who work in their core domain. This means, that the job is on an academic level and their field of studies matches their job as well.

We plot these three types of information for the School of Business and Economics, the faculty of Arts and Social Sciences, the faculty of Psychology and Neuroscience, the faculty of Law, and the faculty of Life Science and Medicine. In the latter faculty, we distinguish between life sciences and medicine as the two parts of this faculty differ substantially in their competencies. Again, we do not report on the faculty of Humanities and Science as we do not have enough observations to comment on the competencies related to this faculty.

\subsubsection{School of Business and Economics}

Figure 4.8 shows the competencies reported by graduates from the School of Business and Economics. Similar to what we saw in Figure 4.I for all Maastricht University graduates together, the ability to analyze and solve problems is the most required competency. Other academic competencies, such as the ability to make clear to others what you mean or communication skills, also score very highly. Knowledge about one's own discipline as well as the ability to apply professional knowledge are reported by more than 8 out of Io respondents working in their core domain. Considering the respondents working in the core domain, the appreciation of cultural aspects and the appreciation of legal and ethical aspects of work are reported relatively little as requirements, but still in more than $50 \%$ of the cases. 
Figure 4.8

Required competencies: SBE graduates working in their core domain

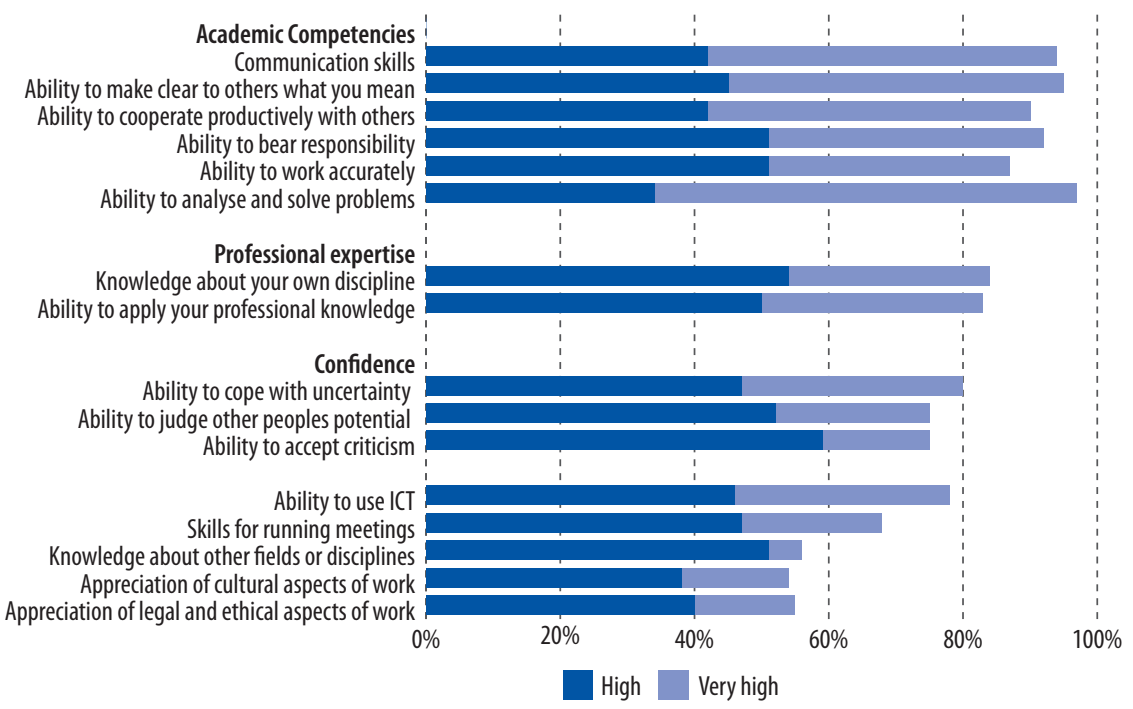

\section{Textbox 4.1}

Competency requirements in the Netherlands and abroad

With $24 \%$ of the $2000-2001$ graduates and $39 \%$ of the $2005-2006$ graduates working abroad, SBE is the faculty with the highest number of graduates working abroad. This is probably related to the large percentage of foreign students at this faculty. It is therefore interesting to see if there is a difference in the competency requirements between graduates working in the Netherlands and graduates working abroad. With respect to five out of six academic competencies, we see that the percentage of graduates mentioning that the extent to which these competencies are required to a high or very extent is higher among those working in the Netherlands than among those working abroad. Only the skill of working accurately is mentioned more often as being required to a high or very high extent among graduates working abroad than among graduates working in the Netherlands. However, if we concentrate on answer category 5 (required on a very high level) it is interesting to observe that these academic competencies are mentioned by a larger percentage of graduates abroad as being required to a very high extent than among graduates in working in the Netherlands. On the other hand, the competencies belonging to the other category, such as the ability to use ICT, skills for running meetings and the appreciation of cultural aspects of work, are mentioned more often by graduates working abroad than by graduates working in the Netherlands. This difference implies that the jobs that SBE graduates have in the Netherlands are different from the jobs SBE graduates have abroad.

Figure 4.9 shows the strengths and weaknesses of their faculty mentioned by SBE graduates. It concerns only those graduates who at the time of the survey - on average eight years after graduation - work in their core domain. Of all SBE graduates, $63 \%$ work in their core domain. Although the ability to analyze and solve problems scores high on the list of strengths, this is not surprising as this holds for all faculties and is probably due to the problem-based learning system. It is remarkable that the ability to cooperate productively with others is mentioned as a strength of their faculty by $52 \%$. This is clearly above the Maastricht University average (37\%) and there is no 
other faculty where this skill is mentioned as a strength so often. On the other hand, knowledge about one's own field or disciplines and appreciation of legal and ethical aspects of work are mentioned less often than average as strengths of SBE.

SBE graduates mention the ability to accept criticism and the appreciation of legal and ethical aspects of work more often as strengths than Maastricht University graduates in general. The competency "skills for running meetings" is mentioned by $14 \%$ of the SBE graduates, compared to $20 \%$ of the Maastricht University graduates in general.

Figure 4.9

Strengths and weaknesses of SBE: graduates working in their core domain

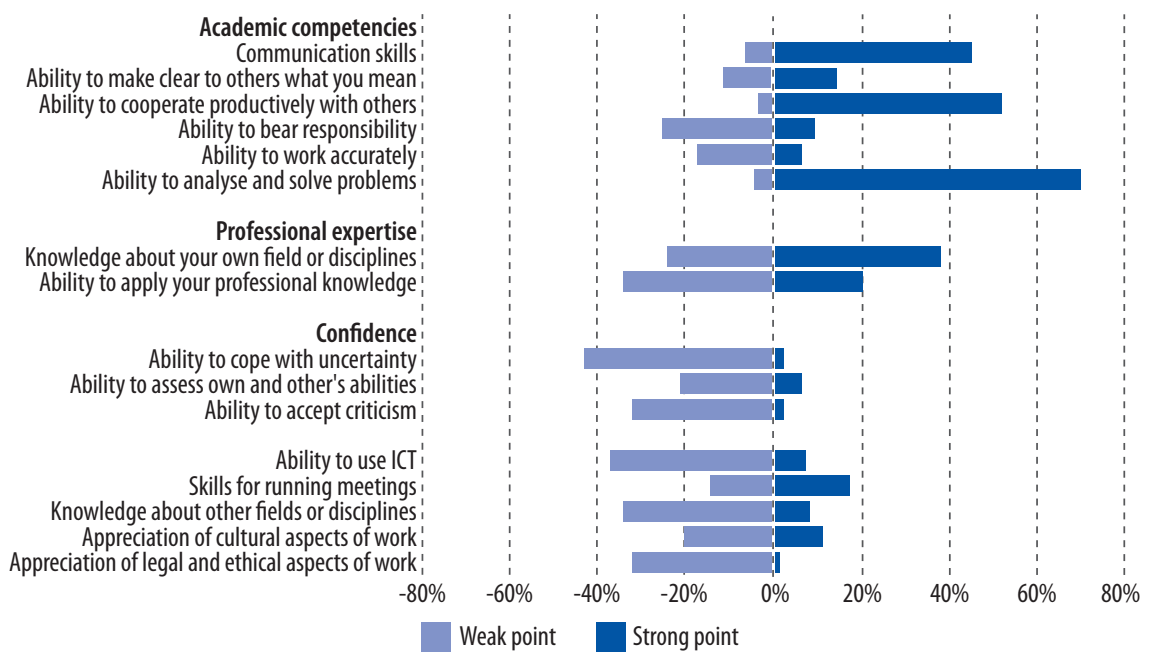

In Figure 4.IO, we compare the percentage of SBE graduates who report that they require certain competencies to a large or very large extent, to the net percentage of graduates who state that these competencies are strengths of SBE. ${ }^{6}$ The dots in the Figure reflect the I6 competencies considered in this report. The comparison between - on the one hand - the level of required competencies and - on the other hand - the degree to which graduates mention competencies as strengths of SBE, indicates the match between the competencies that graduates need in the labour market and the degree to which the university provides these. Like in Figure 4.3, we observe that the match between required competencies and the provision of competencies in terms of weaknesses and strengths is best for academic competencies. Again, this does hold not for the academic competencies 'ability to bear responsibility'(4) and 'ability to work accurately'(5). These competencies are required to a high or very high extent by

6. We talk about the net percentage of graduates, as we subtract the percentage of graduates who report that they experience a certain competency as a weakness from the percentage of graduates who report that they view a certain competency as a strength. 
around $90 \%$ of the SBE graduates, whereas more graduates mention these competencies as weaknesses instead of strengths of SBE. Whereas the match is good for the competency 'knowledge about one's own discipline'(7), this is not the case for the ability to apply professional knowledge (8). The match between the competencies that graduates need in the labour market and the degree to which the university provides these, is also not too good for confidence-related competencies. Whereas these competencies are required to a large or very large extent by at least $75 \%$ of the SBE graduates, many more graduates mention this competency as a weakness than as a strength. Whereas the other competencies (I2-I6) are not required equally often as is the case for academic competencies, SBE nevertheless does not seem to provide these other competencies enough.

\section{Figure 4.10}

Relation between competencies required and strengths: SBE

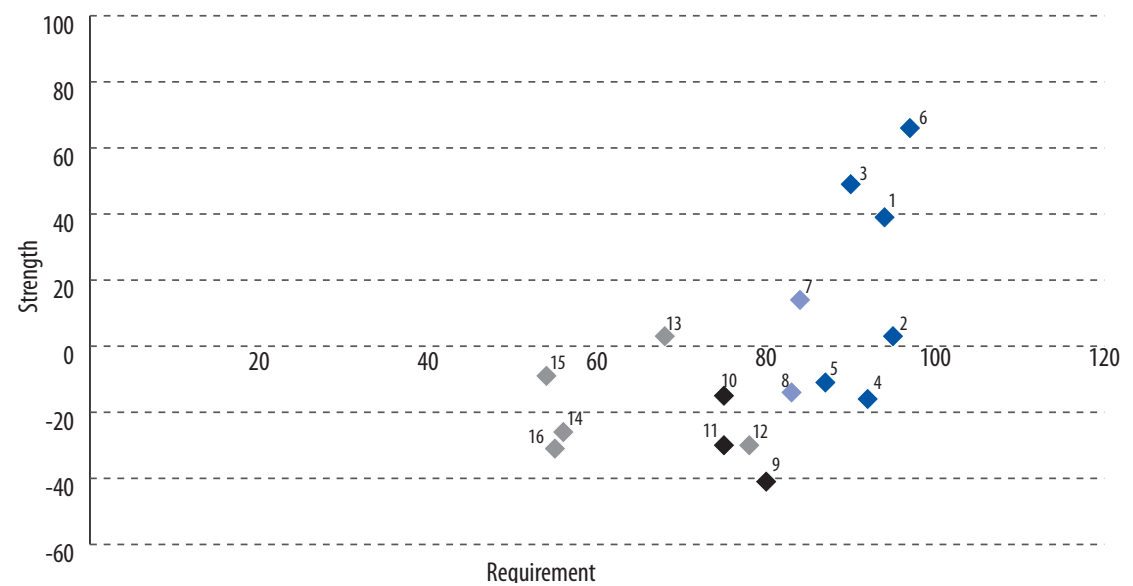

$1=$ communication skills

$3=$ ability to cooperate productively with others

$5=$ ability to work accurately

$7=$ knowledge about your own discipline

$9=$ ability to cope with uncertainty

$11=$ ability to accept criticism

$13=$ skills for running meetings

$15=$ appreciation of cultural aspects of work

$$
\begin{aligned}
& 2=\text { ability to make clear to others what you mean } \\
& 4=\text { ability to bear responsibility } \\
& 6=\text { ability to analyse and solve problems } \\
& 8=\text { ability to apply your professional knowledge } \\
& 10=\text { ability to judge other peoples potential } \\
& 12=\text { ability to use ICT } \\
& 14=\text { knowledge about other fields or disciplines } \\
& 16=\text { appreciation of legal and ethical aspects of work }
\end{aligned}
$$

Graduates were also asked to indicate which percentage of their current level of competencies was acquired during their studies at Maastricht University. For SBE graduates, these percentages are shown in Figure 4.II. With respect to academic competencies, it is interesting to note that graduates from SBE denote for a higher percentage that they acquired every single competency from their studies than is the case on average for all Maastricht University graduates. For example, SBE graduates denote on average that $68 \%$ of their competency to cooperate productively with others was acquired 
during their studies. The average for Maastricht University graduates is 60\%. The appreciation of cultural aspects, on average, was acquired from SBE studies for $53 \%$. The appreciation of legal and ethical aspects of work is the only competency among SBE graduates that was acquired during their studies for less than $40 \%$.

Based on Figures 4.8 to 4.II, we can summarize that graduates from SBE need and appreciate the role of $\mathrm{SBE}$ in providing the ability to analyze and solve problems the most. Whereas this holds for more faculties, SBE turns out to be the best provider of this competency compared to other faculties. This competency is also seen as the greatest strength of SBE. On the other hand, SBE does not perform equally well when it comes to the ability to apply professional knowledge.

\section{Figure 4.11}

Percentage of competencies acquired at SBE

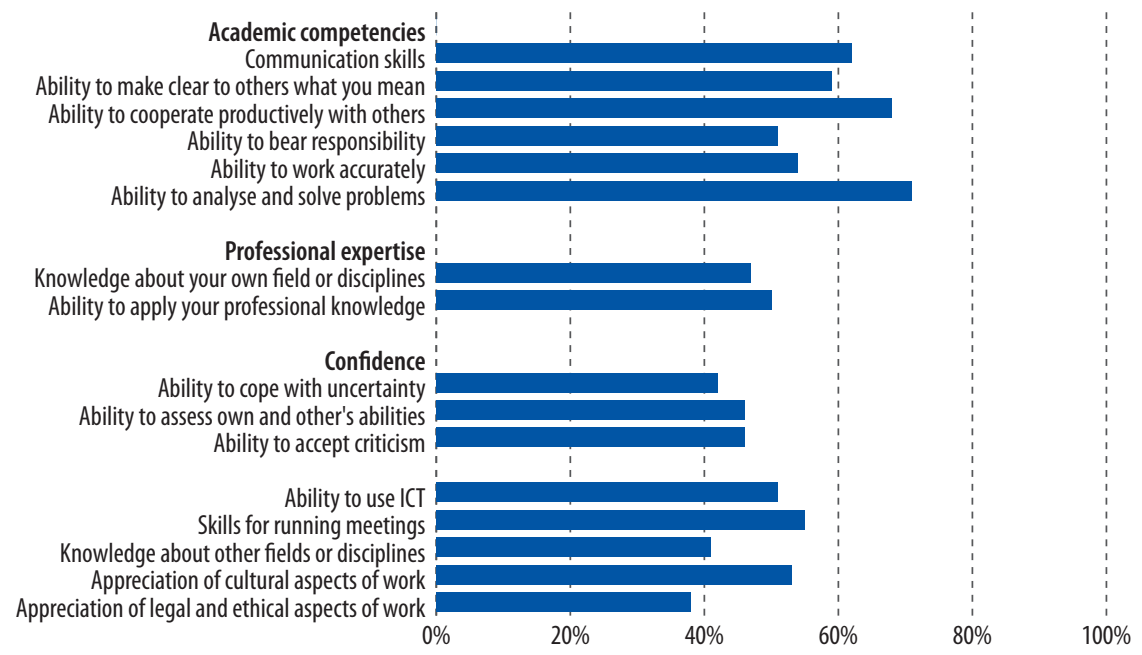

\subsubsection{Faculty of Arts and Social Sciences}

Figure 4.I2 shows the competencies of graduates from the Faculty of Arts and Social Sciences who currently work in their core domain. On average, the academic competencies are required to a large extent compared to other competencies. This holds not only for this specific faculty, but for the university as a whole. Compared to all graduates, the appreciation of cultural aspects of work scores relatively high, as was expected. Whereas this item is reported by less than $50 \%$ of all Maastricht University graduates as being required to a high or very high degree, $68 \%$ of the graduates from the Faculty of Arts and Social Sciences report this as a high or very high requirement.

Figure 4.I3 shows the strengths and weaknesses as perceived by FASoS graduates. It is important to note that both Figures 4.13 and 4.15 are based only on FASoS gradu- 
ates who currently work in their main domain (level and fields of studies). At 40\%, this faculty's percentage is relatively low. But among this group of graduates, $25 \%$ mentions that Maastricht University was good in transferring the ability to work adequately. This percentage is clearly above the Maastricht University average of $11 \%$. Not surprisingly, the appreciation of cultural aspects of work is mentioned most often as a strength among FASoS graduates (20\%), compared to the average of $6 \%$ among Maastricht University graduates as a whole.

\section{Figure 4.12}

Required competencies: FASoS graduates working in their core domain

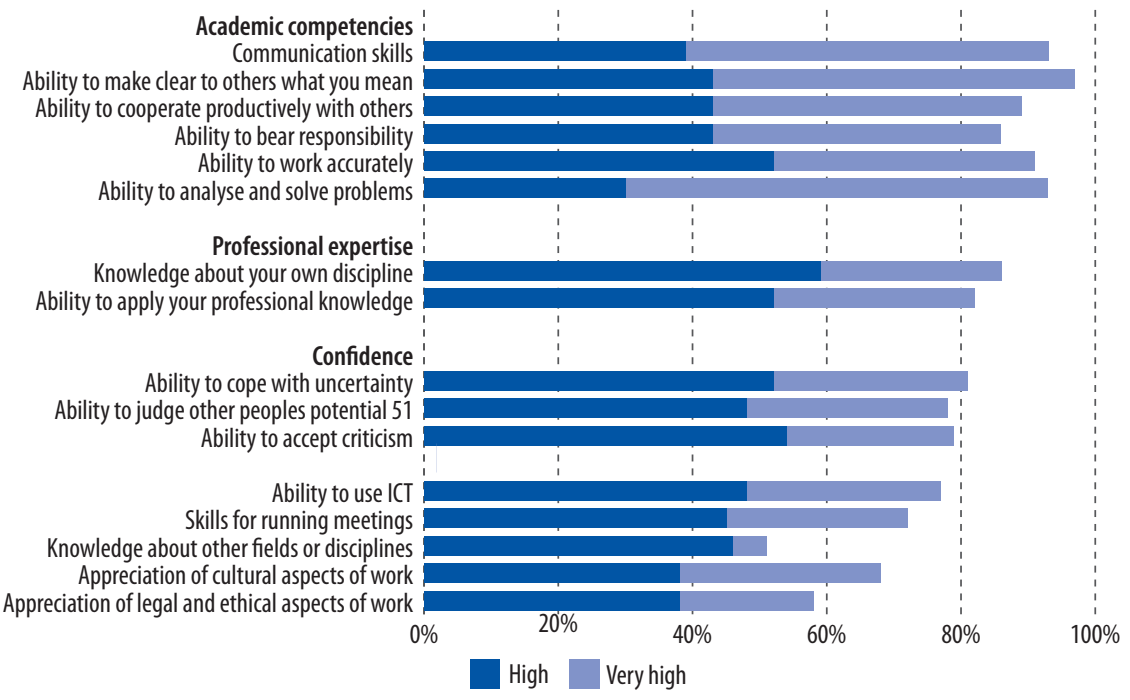

However, graduates from the Faculty of Arts and Science also mention certain competencies quite often as being weaknesses of Maastricht University. Especially the ability to apply professional knowledge and the ability to use ICT are seen as weaknesses by FASoS graduates. More than $50 \%$ of all graduates mention these competencies as weaknesses of Maastricht University. 
Figure 4.13

Strengths and weaknesses: FASoS graduates working in their core domain

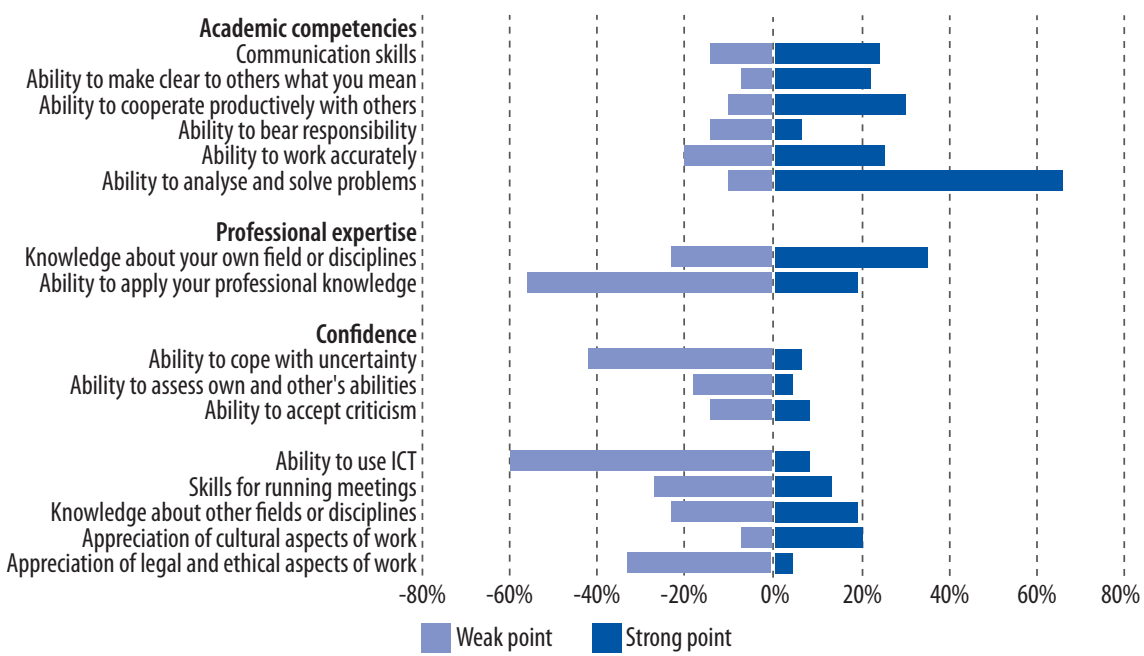

In Figure 4.I4, we compare the percentage of FASoS graduates who report that they require certain competencies to a large or very large extent, to the net percentage of graduates who state that these competencies are a strength of the Faculty of Arts and Social Sciences. ${ }^{7}$ The dots in the Figure reflect the 16 competencies considered in this report. The comparison between - on the one hand - the level of required competencies and - on the other hand - the degree to which graduates mention competencies as strengths of the Faculty of Arts and Social Sciences, indicates the match between the competencies that graduates need in the labour market and the degree to which the faculty provides these. Comparable to the Maastricht University as a whole, we observe in Figure 4.I4 that those competencies which are required most often to a high or very high degree - the academic competencies - are often mentioned as strengths of the Faculty of Arts and Social Sciences. This holds especially for the ability to analyze and solve problems (6). The match with respect to the competencies related to professional expertise is diffuse. Whereas the graduates of the Faculty of Arts and Social Sciences, on average, mention the highly required competency of 'knowledge about own discipline'(7) as a strength of the Maastricht University, this does not hold for the ability to apply professional knowledge. Even though this competency is required to a high or very high extent by $82 \%$ of the graduates, more graduates labels this competency as a weakness than as a strength of the Maastricht University. Also with respect to most other competencies (I2-I6), the match between the required competencies and the degree to which the faculty provides these, is quite weak.

7. We talk about the net percentage of graduates, as we subtract the percentage of graduates who report that they experience a certain competency as a weakness from the percentage of graduates who report that they view a certain competency as a strength. 
Figure 4.14

Relation between competencies required and strengths: Faculty of Arts and Social Sciences

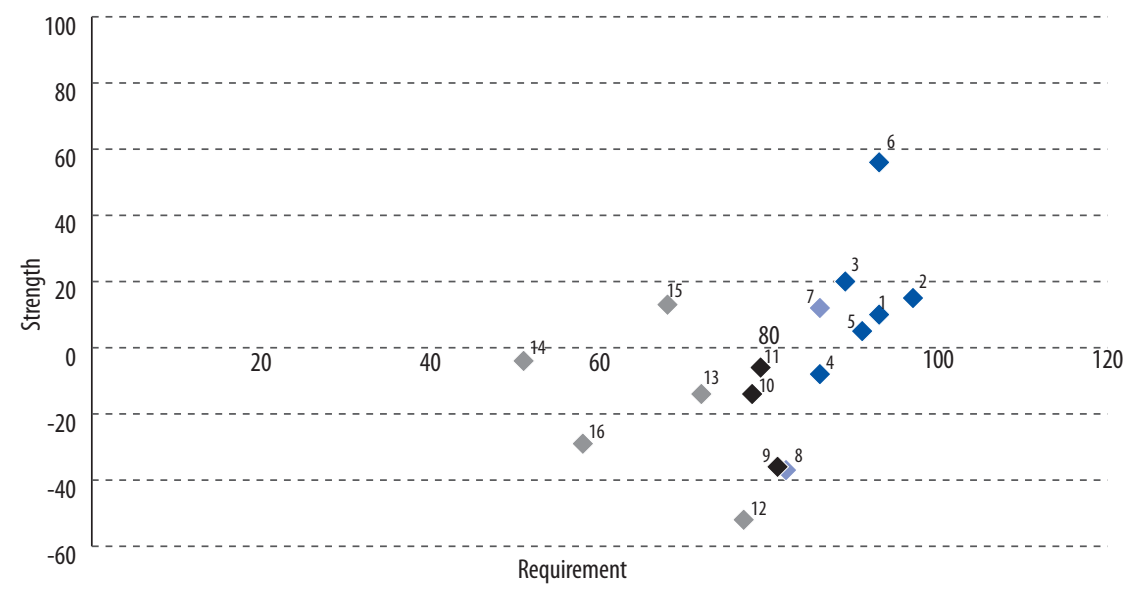

$1=$ communication skills

$3=$ ability to cooperate productively with others

$5=$ ability to work accurately

$7=$ knowledge about your own discipline

$9=$ ability to cope with uncertainty

$11=$ ability to accept criticism

$13=$ skills for running meetings

$15=$ appreciation of cultural aspects of work
$2=$ ability to make clear to others what you mean

$4=$ ability to bear responsibility

$6=$ ability to analyse and solve problems

$8=$ ability to apply your professional knowledge

$10=$ ability to judge other peoples potential

12 = ability to use ICT

$14=$ knowledge about other fields or disciplines

$16=$ appreciation of legal and ethical aspects of work

\section{Figure 4.15}

Percentage of competencies acquired at the Faculty of Arts and Social Sciences

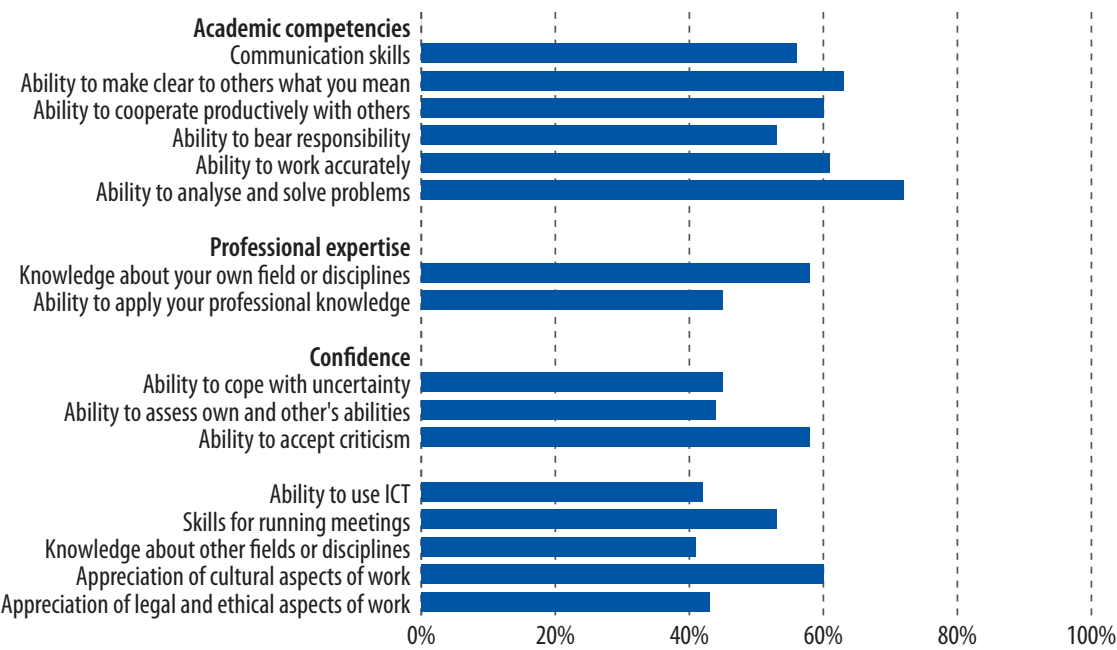


In Figure 4.I5, we report on the percentage of each competency required in graduates' jobs that was acquired at university. For at least 50\%, all academic competencies were acquired at university. Compared to most other faculties, graduates from FASoS report that a relatively large percentage of competencies related to confidence were acquired during their studies. These percentages range between 44 and $58 \%$ for FASoS graduates.

Overall, we can state that graduates from the Faculty of Arts and Social Sciences seem to have most problems finding work in their core domain. ${ }^{8}$ Those graduates who did find a job within their core domain (40\%), seem to require competencies related to confidence to a larger extent than graduates from other faculties. Whereas FASoS graduates report that they acquired between 44 and $58 \%$ of theses competencies during their studies, these competencies are also often mentioned as a weakness of Maastricht University. Like Maastricht University as a whole, a strength of the Faculty of Arts and Social Sciences is the ability to analyze and solve problems and almost $75 \%$ of the required level is acquired during the graduates' studies.

\section{Textbox 4.2}

Competency requirements in the Netherlands and abroad

With an increasing percentage of graduates working outside the Netherlands, it is also of interest to the Faculty of Arts and Social Sciences to compare competency requirements in the Netherlands and abroad. It is striking that, whereas the overall percentage of graduates who mention that professional competencies are required to a high or very high extent is similar among those working in the Netherlands and those working abroad, the percentage of graduates who mention that they need these competencies to a very high extent is much larger among graduates working abroad. Similar to what we found for graduates from the Faculty of Psychology and Neuroscience, graduates working abroad mention that they need ICT to a very high extent more often (52\%) than do graduates working in the Netherlands (25\%). The degree to which knowledge from other fields or disciplines is required is also different among graduates working in the Netherlands compared to graduates working abroad. Whereas $52 \%$ of the graduates abroad require this competency to a large extent, this only holds for $35 \%$ of the graduates working in the Netherlands.

\subsubsection{Faculty of Psychology and Neuroscience}

Figure 4.I6 shows the competencies of graduates from the Faculty of Psychology and Neuroscience $(\mathrm{P} \& \mathrm{~N})$ who work in their core domain. Like the graduates from the other faculties, the graduates from the Faculty of P\&N report that they require academic competencies most in their jobs about eight years after graduation. It is remarkable, though, that the competencies related to confidence are more often indicated as being required to a high or very high degree among graduates from the faculty of $\mathrm{P} \& \mathrm{~N}$ than from Maastricht University on average. ${ }^{9}$

8. See factsheet ROA-F-20I2/3 in which this has been commented on as well. Graduates from the Faculty of Arts and Social Sciences especially seem to have problems finding a horizontal match between their studies and current work.

9. This does not only hold for the Faculty of $P \& N$ but, as we have seen in Section 4.2.2., also for the Faculty of Arts and Social Sciences. 
Figure 4.16

Required competencies: P\&N graduates working in their core domain

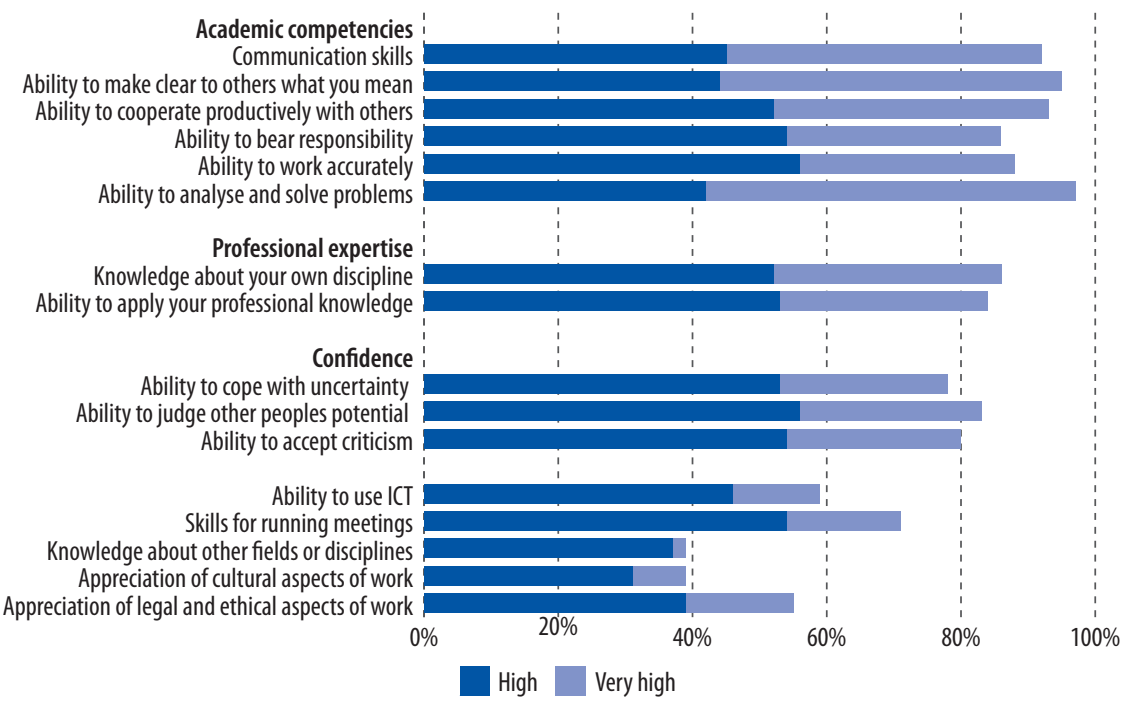

Figure 4.17

Strengths and weaknesses: P\&N graduates working in their core domain

Academic competencies i Communication skills: Ability to make clear to others what you mean! Ability to cooperate productively with others: Ability to bear responsibility Ability to work accurately Ability to analyse and solve problems:

Professional expertise Knowledge about your own field or disciplines Ability to apply your professional knowledge?

Confidence

Ability to cope with uncertainty Ability to assess own and other's abilities: Ability to accept criticism!

Ability to use ICT Skills for running meetings Knowledge about other fields or disciplines: Appreciation of cultural aspects of work! Appreciation of legal and ethical aspects of work $-80 \%$

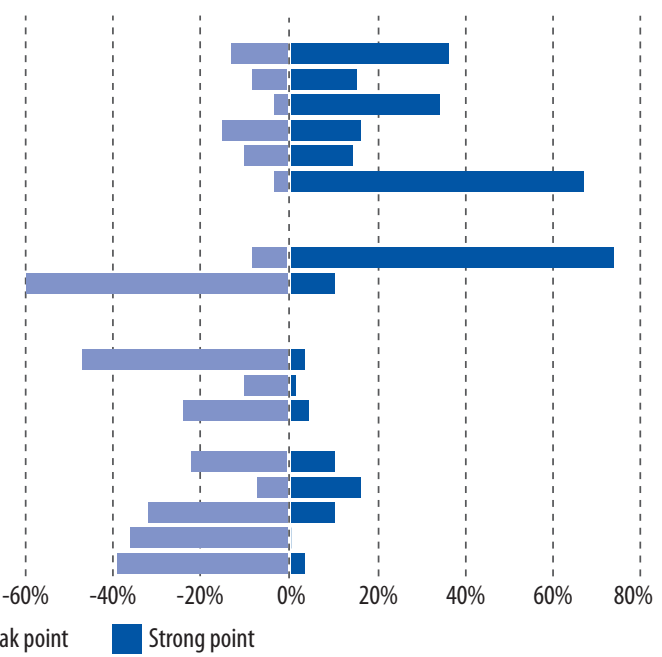

Figure 4.I7 only includes information from graduates from the Faculty of $\mathrm{P} \& \mathrm{~N}$ who actually work in their core domain. This comes down to $63 \%$ of all P\&N graduates. The Figure shows the percentage of graduates denoting a certain competency as a strength or weakness of their study at Maastricht University. The competency mentioned most as being a strength of Maastricht University among P\&N gradu- 
ates, is knowledge about one's own field or discipline. $74 \%$ of the graduates from the Faculty of P\&N report this as a strength of Maastricht University. This is much more than the $47 \%$ among all Maastricht University graduates. On the other hand, the ability to apply professional knowledge is mentioned as a weakness of Maastricht University by $60 \%$. This is also much more than the Maastricht University average $(36 \%)$. Whereas the ability to assess one's own and others' abilities is mentioned only by $\mathrm{I} \%$ as a strength, it is also mentioned by only by IO\% as a weakness. However, for psychologists one would expect that it is very important to assess one's own and others' abilities.

\section{Figure 4.18}

Relation between competencies required and strengths: Faculty of Psychology and Neuroscience

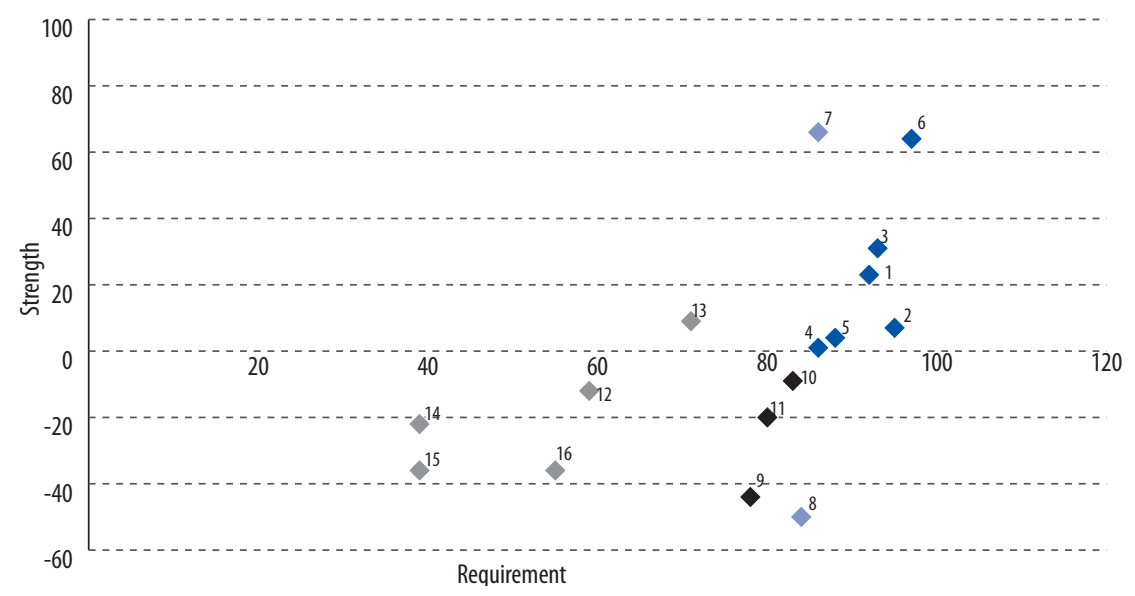

$1=$ communication skills

$3=$ ability to cooperate productively with others

$5=$ ability to work accurately

$7=$ knowledge about your own discipline

$9=$ ability to cope with uncertainty

$11=$ ability to accept criticism

$13=$ skills for running meetings

$15=$ appreciation of cultural aspects of work
$2=$ ability to make clear to others what you mean

$4=$ ability to bear responsibility

$6=$ ability to analyse and solve problems

$8=$ ability to apply your professional knowledge

$10=$ ability to judge other peoples potential

$12=$ ability to use ICT

$14=$ knowledge about other fields or disciplines

$16=$ appreciation of legal and ethical aspects of work

In Figure 4.I8, we compare the percentage of P\&N graduates who report to that they require certain competencies to a large or very large extent, to the net percentage of graduates who state that these competencies are strengths of the Faculty of P\&N. ${ }^{10}$ The dots in the Figure reflect the 16 competencies considered in this report. The comparison between - on the one hand - the level of required competencies and - on the other hand - the degree to which graduates mention competencies as strengths

Io. We talk about the net percentage of graduates, as we subtract the percentage of graduates who report that they experience a certain competency as a weakness from the percentage of graduates who report that they view a certain competency as a strength. 
of the Faculty of $P \& N$, indicates the match between the competencies that graduates need in the labour market and the degree to which the faculty provides these. From Figure 4.18 it becomes clear that this match is very good for two competencies: the ability to analyze and solve problems (6) and knowledge about one's own discipline (7). Both competencies are mentioned by almost all graduates as being required to a large or very large extent, while at the same time more than $60 \%$ of the graduates report these competencies as being strengths of the Maastricht University. ${ }^{\text {II }}$ On the other hand, there are also two competencies that are required to a high or very high extent by about $80 \%$ of the graduates where the net percentage of graduates denoting these competencies as weaknesses of the Maastricht University is over $40 \%$. It concerns the ability to apply professional knowledge (8) and the ability to cope with uncertainty (9). In general, we can state that the match for confidence competencies (9-II) and 'other competencies'(I2-I6) is not too good. However, since the competencies 'knowledge about other fields or discipline'(I4) and 'appreciation of cultural aspects of work'(I5) are only mentioned by one out of three graduates as being required to a high or very high extent, it should not be a problem that - on average - graduates mention these competencies as weaknesses of the Maastricht University.

In Figure 4.I9, we report the percentage of competencies that $P \& N$ graduates acquired during their studies at Maastricht University. In line with the Maastricht University average, $\mathrm{P} \& \mathrm{~N}$ graduates report that the ability to bear responsibility was acquired for less than 50\% during their studies at Maastricht University. For the other academic competencies, this percentage is at least $50 \%$. In line with the findings from Figure 4.I7, P\&N graduates report to have acquired $52 \%$ of their required knowledge about their own field or discipline during their studies at Maastricht University. On average, P\&N graduates only report to have acquired $40 \%$ of their ability to apply professional knowledge during their studies at Maastricht University. Also with respect to the appreciation of cultural aspects of work, $P \& N$ graduates report that they acquired most of these competencies during their work experience and not from Maastricht University. Only $26 \%$ of the required appreciation of cultural aspects of work was acquired during their studies at Maastricht University.

Based on Figures 4.I6 to 4.I9, we can state that both the strengths and weaknesses of the faculty of $P \& N$ are related to professional expertise. Knowledge about one's own field or discipline is mentioned as a strength by almost $75 \%$, and graduates report that Maastricht University has provided them with slightly more than 50\% of this knowledge. The picture is totally different for the ability to apply professional knowledge. This is mentioned by $60 \%$ of the P\&N graduates as a weakness of Maastricht University.

II. In fact, $67 \%$ of the graduates mention the ability to analyze and solve problems as a strength, but $3 \%$ mentions this as a weakness. With respect to knowledge about one's own discipline, $74 \%$ of the graduates mentions this as a strength and $8 \%$ mentions this as a weakness. 
Figure 4.19

Percentage of competencies acquired at the Faculty of Psychology and Neuroscience

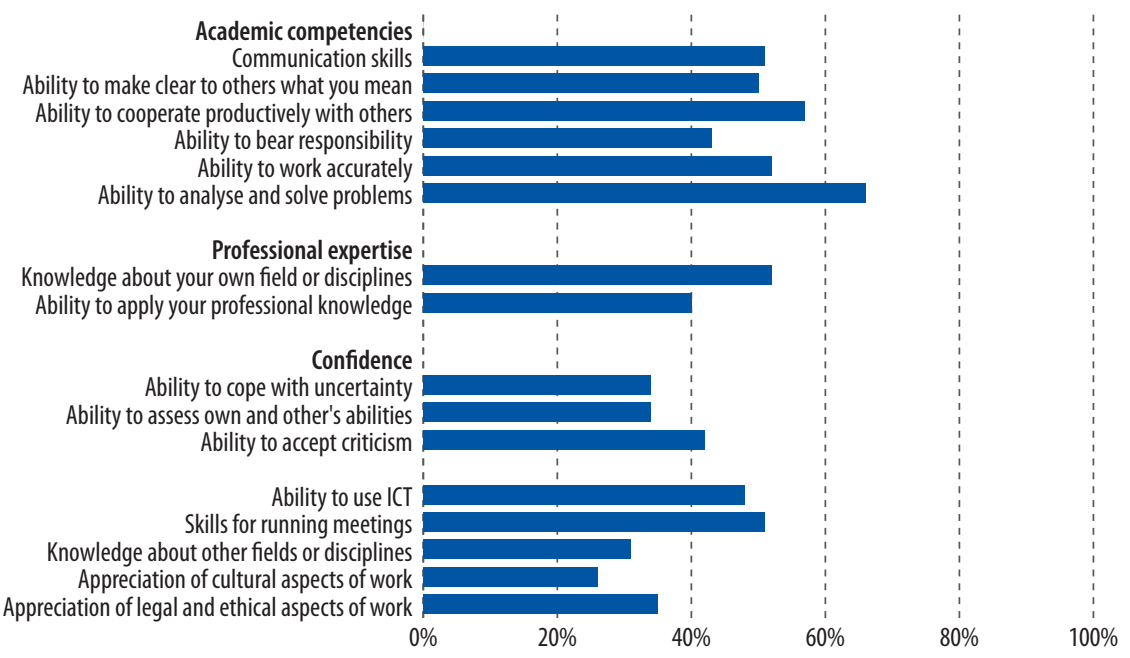

\section{Textbox 4.3}

Competency requirements in the Netherlands and abroad

Also the Faculty of Psychology and Neurosciences knows an increasing number of graduates that are working abroad, facing different competency requirements than the graduates staying in the Netherlands. The difference with respect to the extent in which academic competencies are required in the Netherlands and abroad is larger among graduates from N\&P than from the SBE. Whereas communication skills are by about $90 \%$ of the graduates working in the Netherlands required to a high or very high extent, this holds for almost $100 \%$ of the graduates working abroad. On the other hand, making clear to others what you mean is required to a large or very large extent by nearly $100 \%$ of all graduates working in the Netherlands, compared to $90 \%$ working abroad. Also working accurately is mentioned much more among graduates working in the Netherlands than among graduates working abroad (difference of $16 \%$ ). Graduates working abroad (81\%) on the other hand, require ICT much more often than graduates working in the Netherlands (54\%) to a high or very high extent.

\subsubsection{Faculty of Law ${ }^{12}$}

In Figure 4.20, we show the percentage of graduates from the Faculty of Law that mention that within their current job in the core domain specific competencies are required to a very high or high extent. Among the academic competencies, there is only one competency - the ability to cooperate productively with others - that is mentioned less than 90\%. Especially the ability to make clear to others what you mean and the ability to analyze and solve problems is required in the jobs of almost all former law students (98\%, respectively, 97\%). Not surprisingly, the appreciation of legal and ethical aspects of work is also required to a (very) large extent for most

I2. For the Faculty of Law, we do not provide information with respect to competencies requirements when working abroad versus when working in the Netherlands as the number of respondents working abroad is too small to provide results. 
law graduates (88\%). Appreciation of cultural aspects of work, knowledge about other fields or disciplines and skills for running meetings are competencies that a are less often required to a high or very high extent.

\section{Figure 4.20}

Required competencies: Law graduates working in their core domain

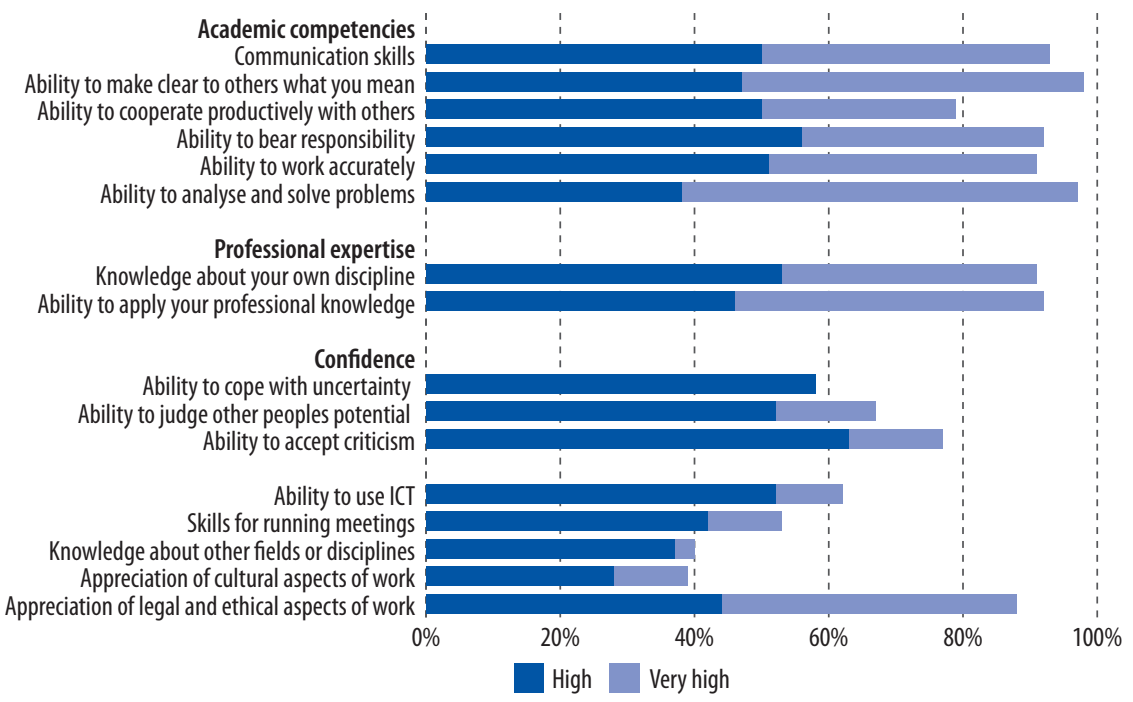

The percentage of graduates working in their core domain is largest among the graduates from the Law faculty. $72 \%$ of these graduates found (after on average eight years) a job in their field of studies and at an academic level. Also remarkable in comparison to other faculties is the percentage of law graduates reporting that the ability to apply professional knowledge is a strength of Maastricht University. This can be seen in Figure 4.2I that shows the strengths and weaknesses of law graduates working in their core domain. $46 \%$ of the law graduates report the ability to apply professional knowledge as a strength of Maastricht University, compared to $28 \%$ for Maastricht University in general. On the other hand, communication skills are much less than average mentioned to be a strength (I $2 \%$ compared to $40 \%$ ). 
Figure 4.21

Strengths and weaknesses: Law graduates working in their core domain

Academic competencies: Communication skillsi Ability to make clear to others what you mean: Ability to cooperate productively with others: Ability to bear responsibility; Ability to work accurately Ability to analyse and solve problems

Professional expertise: Knowledge about your own field or disciplines Ability to apply your professional knowledge

Confidence Ability to assess own and other's abilities Ability to accept criticism

Ability to use ICT Skills for running meetings Knowledge about other fields or disciplines: Appreciation of cultural aspects of work Appreciation of legal and ethical aspects of work! $-80 \%$

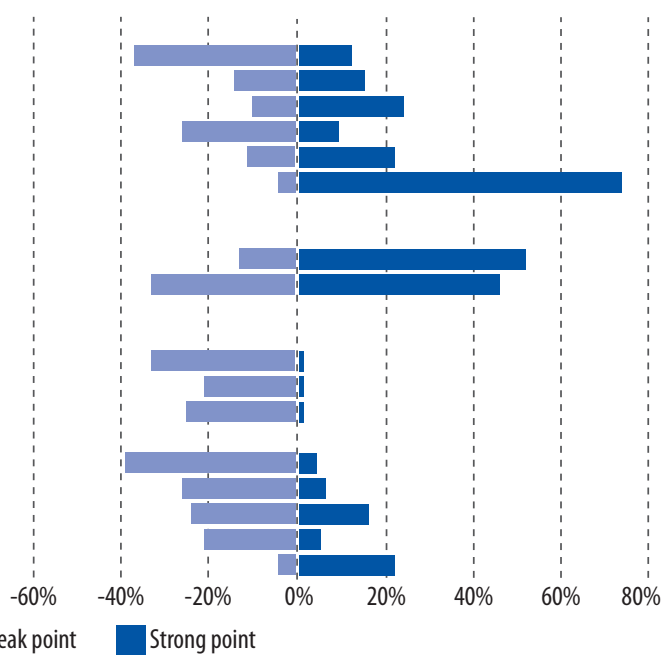

Figure 4.22

Relation between competencies required and strengths: Faculty of Law

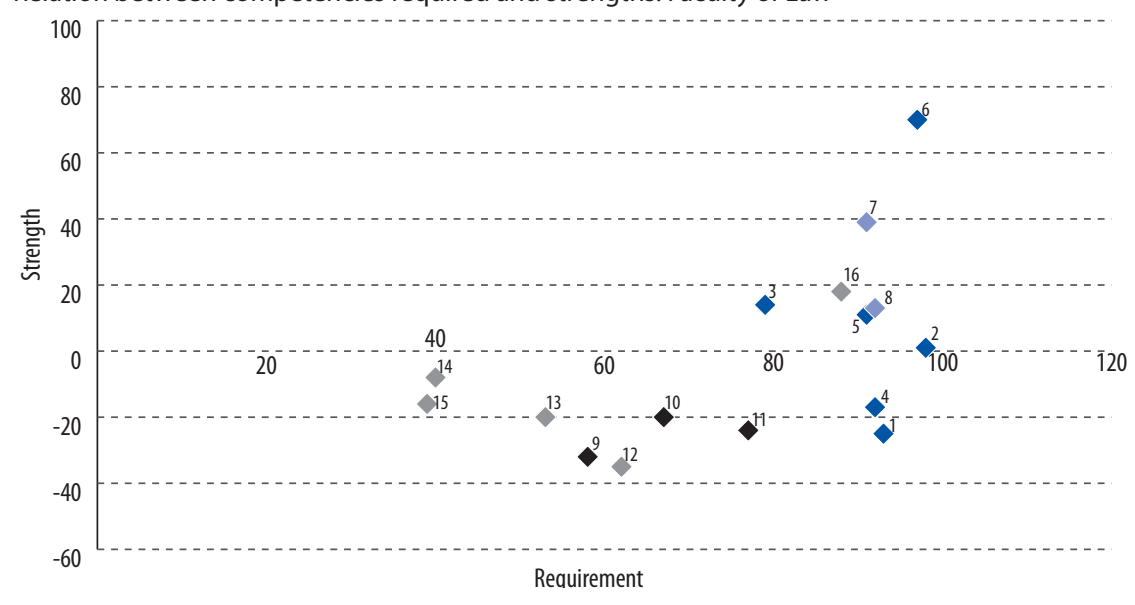

$1=$ communication skills

$3=$ ability to cooperate productively with others

$5=$ ability to work accurately

$7=$ knowledge about your own discipline

$9=$ ability to cope with uncertainty

$11=$ ability to accept criticism

$13=$ skills for running meetings

$15=$ appreciation of cultural aspects of work
$2=$ ability to make clear to others what you mean

$4=$ ability to bear responsibility

$6=$ ability to analyse and solve problems

$8=$ ability to apply your professional knowledge

$10=$ ability to judge other peoples potential

$12=$ ability to use ICT

$14=$ knowledge about other fields or disciplines

$16=$ appreciation of legal and ethical aspects of work 
In Figure 4.22, we compare the percentage of law graduates who report that they require certain competencies to a large or very large extent, to the net percentage of graduates who state that these competencies are strengths of the Faculty of Law. ${ }^{13}$ The dots in the Figure reflect the I6 competencies considered in this report. The comparison between - on the one hand - the level of required competencies and - on the other hand - the degree to which graduates mention competencies as strengths of the Faculty of Law, indicates the match between the competencies that graduates need in the labour market and the degree to which the faculty provides these. In Figure 4.22 we see that this match is clearly achieved for the ability to analyze and solve problems (6). Not only do graduates require this competency to a high or very high extent, $70 \%$ of the graduates view this competency as a strength of the Maastricht University. This is in sharp contrast with communication skills. $93 \%$ of the graduates mention that they need this competency in their current jobs to a large or very large extent, but $25 \%$ of the graduates experience this competency as a weakness of the Maastricht University. ${ }^{14}$ It is interesting to note the good match with respect to professional expertise, which is much better than in other faculties. Both competencies belonging to professional expertise ( 7 en 8 ) are required to a large or very large extent by about $90 \%$ of the graduates, and for both competencies it holds that more graduates view them as strengths than as weaknesses. Similar to other faculties, we observe a weak match between the competencies related to confidence that graduates need in the labour market and the degree to which the faculty provides these competencies. The match with respect to some of the other competencies (I2 en I3) is weak as well. Since the competencies 'knowledge about other fields or discipline'(I4) and 'appreciation of cultural aspects of work'( 15 ) are only mentioned by $40 \%$ of the graduates as being required to a high or very high extent, it should not be a problem that these competencies are experienced as weaknesses of the Maastricht University.

In Figure 4.23, we report on the percentage of competencies required in graduates' jobs that is acquired during their studies at the Faculty of Law from Maastricht University. Compared to Maastricht University in general, law graduates report to have acquired a lower percentage of academic competency requirements from Maastricht University. As can be expected from Figures 4.20 and 4.2I, most skills related to the competency confidence have been acquired to the largest extent after leaving Maastricht University. This does not only hold for the group of skills related to confidence. Only the ability to cooperate productively with others, the ability to work accurately, the ability to analyze and solve problems and the appreciation of legal and ethical aspects of work are acquired to a larger extent from Maastricht University than from their work experience.

13. We talk about the net percentage of graduates, as we subtract the percentage of graduates who report that they experience a certain competency as a weakness from the percentage of graduates who report that they view a certain competency as a strength.

I4. In fact, $37 \%$ even mentions communication skills as a weakness of the Maastricht University, but I $2 \%$ mentions this competency as a strength, so that the net percentage is $-25 \%$. 
Figure 4.23

Percentage of competencies acquired at the Faculty of Law

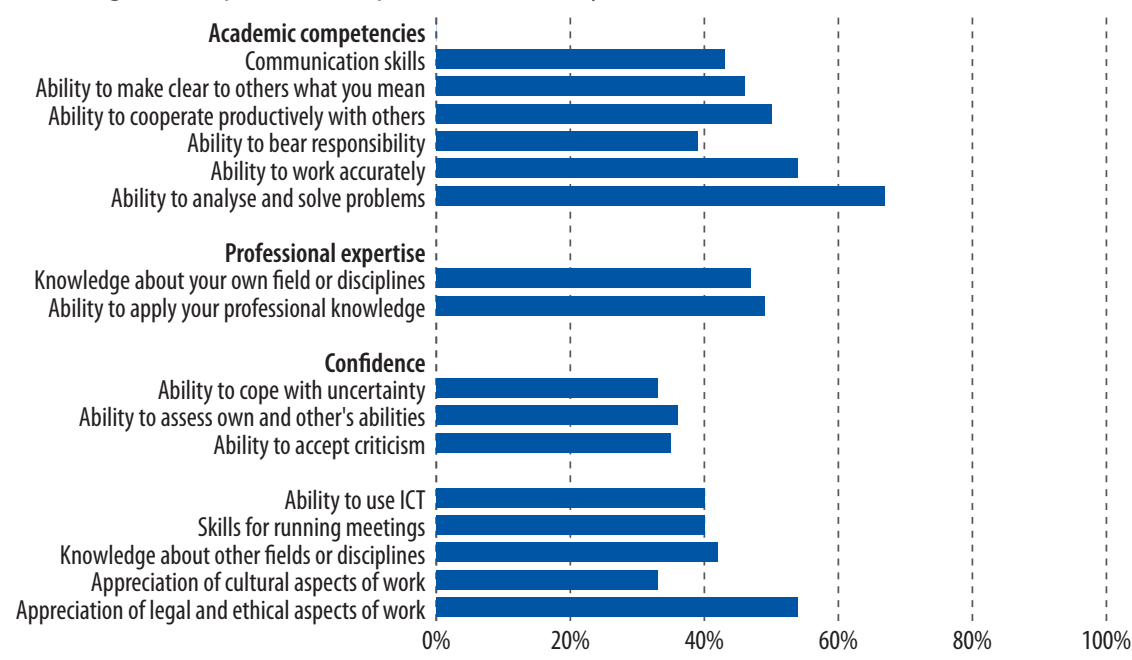

The Faculty of Law is appreciated by its graduates for the ability to analyze and solve problems, and as well as most other faculties, for the ability to apply professional knowledge. Nevertheless, for most competencies, graduates state that they acquired the necessary skills and knowledge mainly during their time on the labour market and not during their studies at Maastricht University. This holds especially for competencies related to confidence. Not surprisingly, these are often mentioned as weaknesses of Maastricht University.

\subsubsection{Faculty of Health, Medicine and Life Sciences ${ }^{15}$}

The Faculty of Health, Medicine and Life Sciences is quite diffuse. Therefore, we distinguish between - on the one hand - graduates from Health and Life Sciences and - on the other - graduates from Medicine.

\subsubsection{Health and Life Sciences}

In Figure 4.24, the percentage graduates from health and life sciences is reported who need specific competencies to a high or very high degree while working in their core domain. Again, the results for this faculty show the importance of the items grouped under the title academic competencies.

15. For the Faculty Health, Medicine and Life Sciences, we do not provide information with respect to competencies requirements when working abroad versus when working in the Netherlands as the number of respondents working abroad is too small to provide results. 
Figure 4.24

Required competencies: Health and Life Sciences graduates working in their core domain

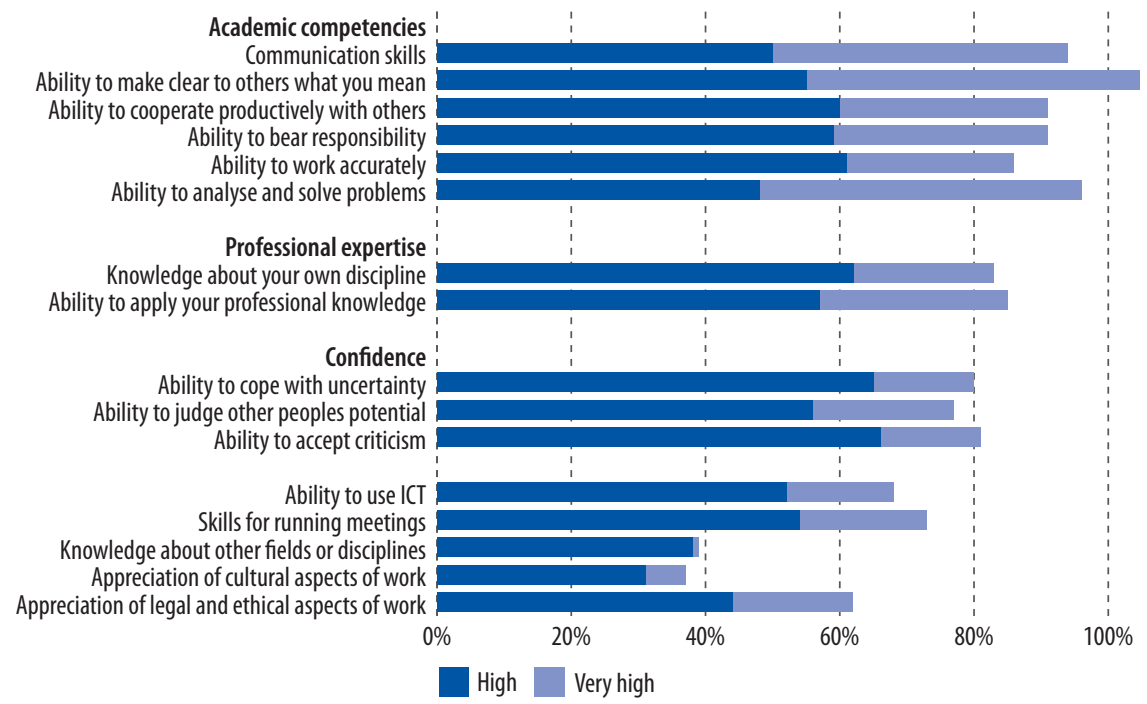

Figure 4.25 plots the strengths and weaknesses of Maastricht University as perceived by graduates from Health and Life Sciences. Both this Figure and Figure 4.27 are based only on graduates who work in their core domain. Among the graduates of Health and Life Sciences, 6r\% work at an academic level in their field of studies. The ability to apply professional knowledge is mentioned as a strength more often by this group of graduates (71\%) than by Maastricht University graduates in general (67\%). Even though the ability to apply professional knowledge is required to a large extent by $95 \%$ of all graduates from Health and Life Sciences, this competency is mentioned as a weakness of Maastricht University by more than $40 \%$ of the graduates. The ability to use ICT is also mentioned as a weakness of Maastricht University by about $40 \%$. 
Figure 4.25

Strengths and weaknesses: Health and Life Sciences graduates working in their core domain

Academic competencies Communication skills Ability to make clear to others what you mean! Ability to cooperate productively with others: Ability to bear responsibility Ability to work accurately Ability to analyse and solve problems:

Professional expertise Knowledge about your own field or disciplines: Ability to apply your professional knowledge

Ability to cope with uncertainty Ability to assess own and other's abilities: Ability to accept criticism?

Ability to use ICT

Skills for running meetings

Knowledge about other fields or disciplines: Appreciation of cultural aspects of work: Appreciation of legal and ethical aspects of work!

$-80 \%$

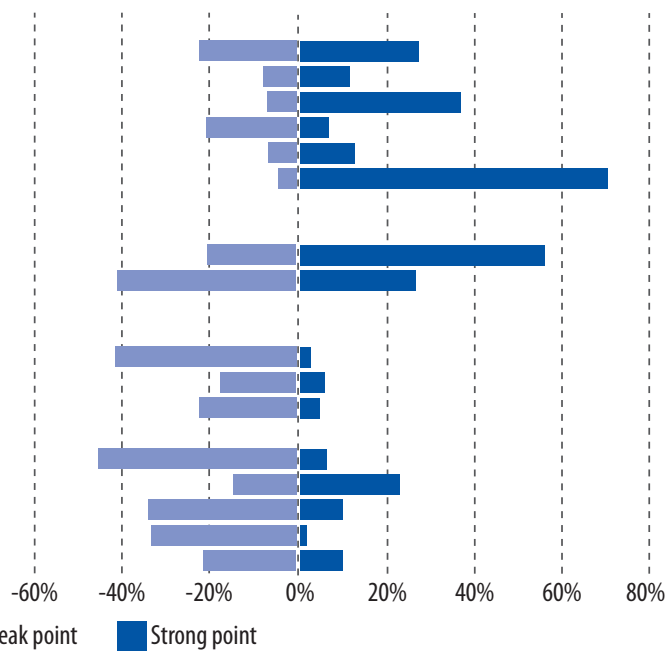

\section{Figure 4.26}

Relation between competencies required and strengths: Health and Life Sciences

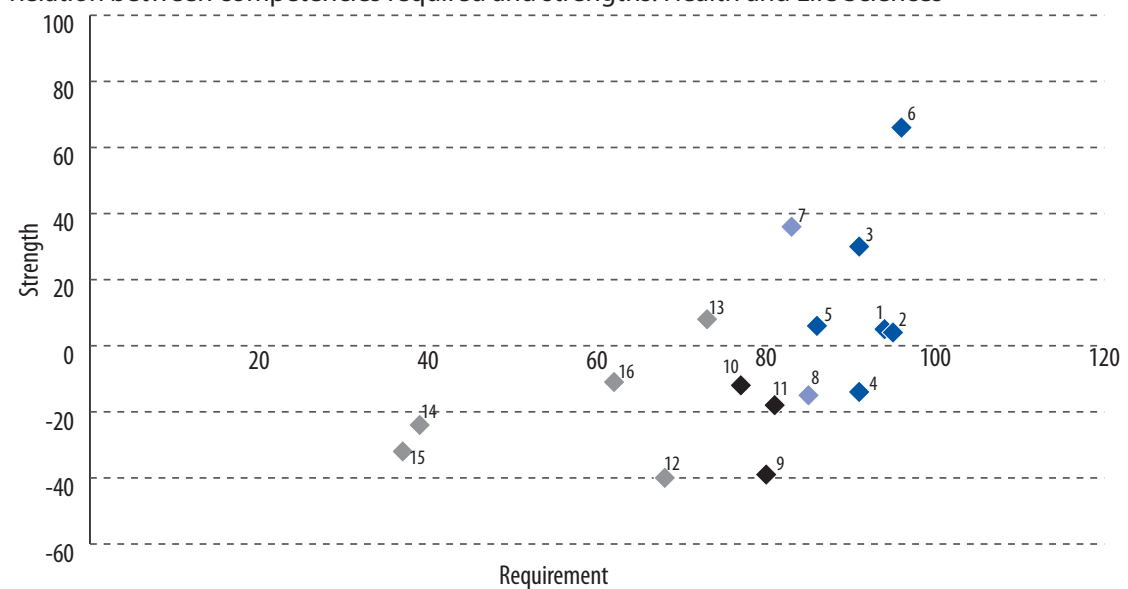

$1=$ communication skills

$3=$ ability to cooperate productively with others

$2=$ ability to make clear to others what you mean

$5=$ ability to work accurately

$7=$ knowledge about your own discipline

$9=$ ability to cope with uncertainty

$11=$ ability to accept criticism

$13=$ skills for running meetings

$15=$ appreciation of cultural aspects of work

$4=$ ability to bear responsibility

$6=$ ability to analyse and solve problems

$8=$ ability to apply your professional knowledge

$10=$ ability to judge other peoples potential

$12=$ ability to use ICT

$14=$ knowledge about other fields or disciplines

$16=$ appreciation of legal and ethical aspects of work 
In Figure 4.26, we compare the percentage of Health and Life Sciences graduates who report that they require certain competencies to a large or very large extent, to the net percentage of graduates who state that these competencies are strengths of the Maastricht University. ${ }^{16}$ The dots in the Figure reflect the 16 competencies considered in this report. The comparison between - on the one hand - the level of required competencies and - on the other hand - the degree to which graduates mention competencies as strengths of the Maastricht University, indicates the match between the competencies that graduates need in the labour market and the degree to which their faculty provides these. The competencies located in the upper right part of the graph have the best match: these competencies are highly required at the labour market, and are at the same time mentioned often as strengths of the Maastricht University. With the exception of the ability to work accurately, all academic competencies are observed in the upper right part of the graph. The best match is observed for the ability to analyze and solve problems (6). The competencies related to confidence are mentioned by more than 50\% of the Health and Life Sciences graduates as being required to a high or very high extent. Nevertheless, they are much more often mentioned as weaknesses than as strengths of the Maastricht University. This shows some unbalance in the needs on the labour market and the provision of competencies by the Maastricht University. Most 'other competencies' are also more often mentioned as weaknesses than as strengths of the Maastricht University, but these competencies are also not seen as important or very important for the graduates' current jobs, so that we cannot really speak of unbalances.

Figure 4.27 plots the percentages of the required competencies that are acquired during the study period at Maastricht University as perceived by graduates from Health and Life Sciences. For most competencies, the work floor seems to have played a bigger role in acquiring these competencies than Maastricht University. This does not only hold for the graduates of Health and Life Sciences, but for all Maastricht University graduates. The graduates of Health and Life Sciences indicate percentages here that are very close to the Maastricht University average. $65 \%$ of the ability to analyze and solve problems is acquired during their studies. Less than $40 \%$ of the knowledge about other fields or disciplines and the appreciation of cultural aspects of work is acquired at Maastricht University.

Overall, for about $95 \%$ of the graduates from Health and Life Sciences the ability to apply professional knowledge is required to a large or very large extent. Nevertheless, only $48 \%$ of this competency is acquired at Maastricht University. It comes as no surprise that $48 \%$ of the graduates mentioned this skill - the ability to apply professional knowledge - as a weakness of Maastricht University. The ability to analyze and solve problems and the ability to cooperate productively with others are perceived as strengths among graduates from Health and Life Sciences.

I6. We talk about the net percentage of graduates, as we subtract the percentage of graduates who report that they experience a certain competency as a weakness from the percentage of graduates who report that they view a certain competency as a strength. 
Figure 4.27

Percentage of competencies acquired at Health and Life Sciences

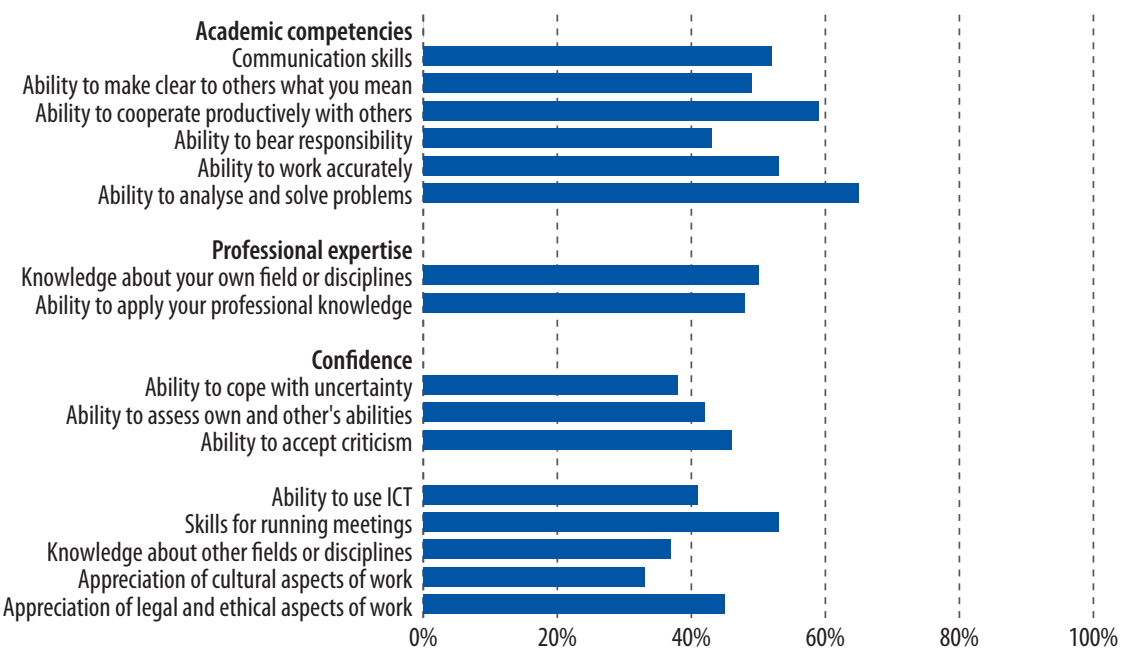

\subsubsection{Medicine}

Figure 4.28 plots the percentages of graduates from Medicine working in the core domain who indicate that specific competencies are required to a large or very large extent in their current job. Compared to other Maastricht University graduates, it is remarkable that not only the academic competencies are indicated by more than $90 \%$ of the graduates as being required to a high or very high extent, but also the competencies related to professional expertise. Skills for running meetings and knowledge about other fields or disciplines are not often required to a high or very high extent among medicine graduates.

Figure 4.29 reports the strengths and weaknesses as perceived by medicine graduates. More than $80 \%$ of the medicine graduates mention communication skills as a strength of Maastricht University. This is clearly above the Maastricht University average of 40. Other competencies that are often mentioned as strengths are the ability to analyze and solve problems ( $5 \mathrm{I} \%)$ and the ability to apply professional knowledge (43\%). These competencies are also quite often mentioned by Maastricht University graduates as a whole ( $67 \%$ and $28 \%$ respectively). It is remarkable that knowledge about one's own field or discipline and the ability to cope with uncertainty are mentioned relatively often as weaknesses of Maastricht University (39\% and $42 \%$ respectively). 
Figure 4.28

Required competencies: Medicine graduates working in their core domain

Academic competencies Communication skills

Ability to make clear to others what you mean Ability to cooperate productively with others

Ability to bear responsibility

Ability to work accurately

Ability to analyse and solve problems

Professional expertise

Knowledge about your own discipline

Ability to apply your professional knowledge

Confidence

Ability to cope with uncertainty

Ability to judge other peoples potential Ability to accept criticism

Ability to use ICT

Skills for running meetings

Knowledge about other fields or disciplines

Appreciation of cultural aspects of work

Appreciation of legal and ethical aspects of work

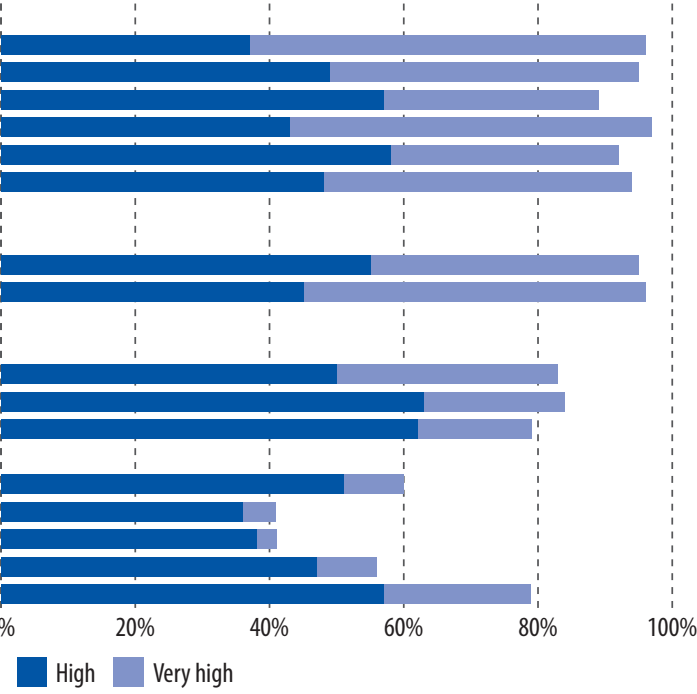

Figure 4.29

Strengths and weaknesses: Medicine graduates working in their core domain

Academic competencies: Communication skills:

Ability to make clear to others what you mean! Ability to cooperate productively with others!

Ability to bear responsibility:

Ability to work accurately!

Ability to analyse and solve problems:

Professional expertise! Knowledge about your own field or disciplines! Ability to apply your professional knowledge?

Confidence :

Ability to cope with uncertainty: Ability to assess own and other's abilities! Ability to accept criticism!

Ability to use ICT:

Skills for running meetingsi'

Knowledge about other fields or disciplines!

Appreciation of cultural aspects of work! Appreciation of legal and ethical aspects of work!

Weak point

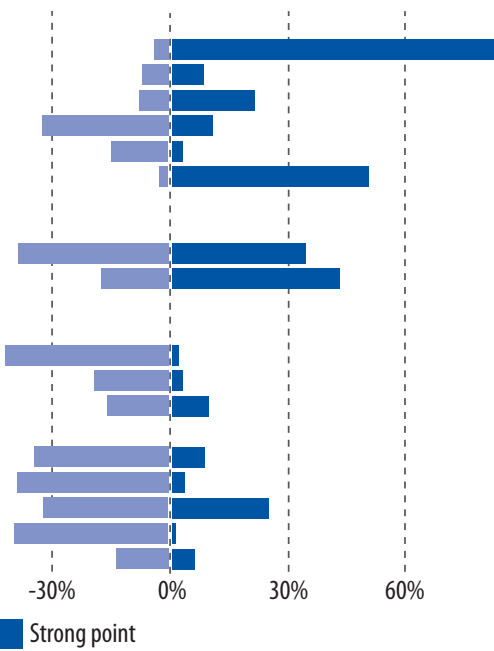

$90 \%$ 
Figure 4.30

Relation between competencies required and strengths: Medicine

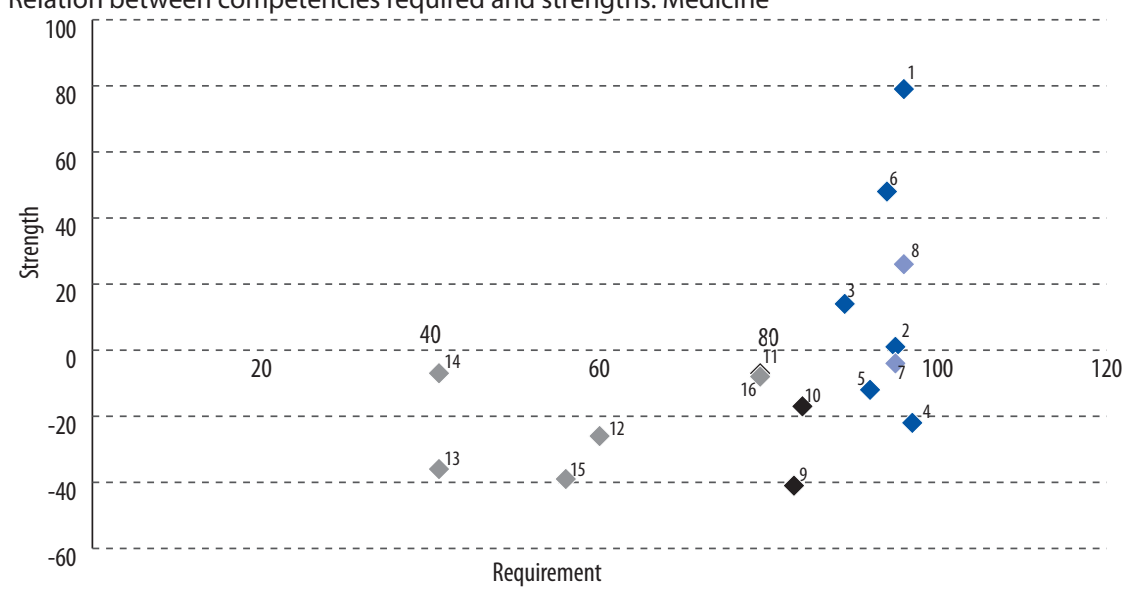

$1=$ communication skills

$3=$ ability to cooperate productively with others

$2=$ ability to make clear to others what you mean

$4=$ ability to bear responsibility

$6=$ ability to analyse and solve problems

$5=$ ability to work accurately

$8=$ ability to apply your professional knowledge

$7=$ knowledge about your own discipline

$10=$ ability to judge other peoples potential

$9=$ ability to cope with uncertainty

$12=$ ability to use ICT

$11=$ ability to accept criticism

$13=$ skills for running meetings

$15=$ appreciation of cultural aspects of work

$14=$ knowledge about other fields or disciplines

$16=$ appreciation of legal and ethical aspects of work

In Figure 4.30, we compare the percentage of medicine graduates who report that they require certain competencies to a large or very large extent, to the net percentage of graduates who state that these competencies are strengths of the Maastricht University. ${ }^{17}$ The dots in the Figure reflect the 16 competencies considered in this report. The comparison between - on the one hand - the level of required competencies and - on the other hand - the degree to which graduates mention competencies as strengths of the Maastricht University, indicates the match between the competencies that medicine graduates need in the labour market and the degree to which their faculty provides these. As we can see from the Figure, most competencies that are required to a high or very high extent in the labour market for medicine graduates, are more often mentioned as strengths of the Maastricht University than as weaknesses. The match between labour market requirements on the one hand, and the strength of the Maastricht University on the other, is especially high for communication skills (I) and the ability to analyze and solve problems (6). However, there are also some competencies that are required to a high or very high degree by at least $90 \%$ of the graduates and are more often mentioned as weaknesses than as strengths of the

17. We talk about the net percentage of graduates, as we subtract the percentage of graduates who report that they experience a certain competency as a weakness from the percentage of graduates who report that they view a certain competency as a strength. 
Maastricht University. This concerns for example the ability to bear responsibility (4), the ability to work accurately (5) and even knowledge about one's own expertise (7). All competencies related to confidence and belonging to the 'other competencies' are mentioned more often as weaknesses than as strengths of the Maastricht University. However, this does not automatically imply a weak match between labour market requirements and the provision of competencies by the Maastricht University. It is questionable whether competencies required to a large or very large extent by less than $50 \%$ of the medicine graduates should have a high priority for the Maastricht University in providing these competencies to its students.

In line with Figure 4.29, Figure 4.3I, in which the percentage of competencies acquired at Maastricht University are reported, shows that most of the communication skills are acquired at Maastricht University. More than two thirds of the required skill level is acquired during the graduates' studies at the medicine faculty. The ability to bear responsibility is mentioned by almost one third as a weakness of Maastricht University, not even I\% mentions this competency as a strength.

Figure 4.31

Percentage of competencies acquired at Maastricht University

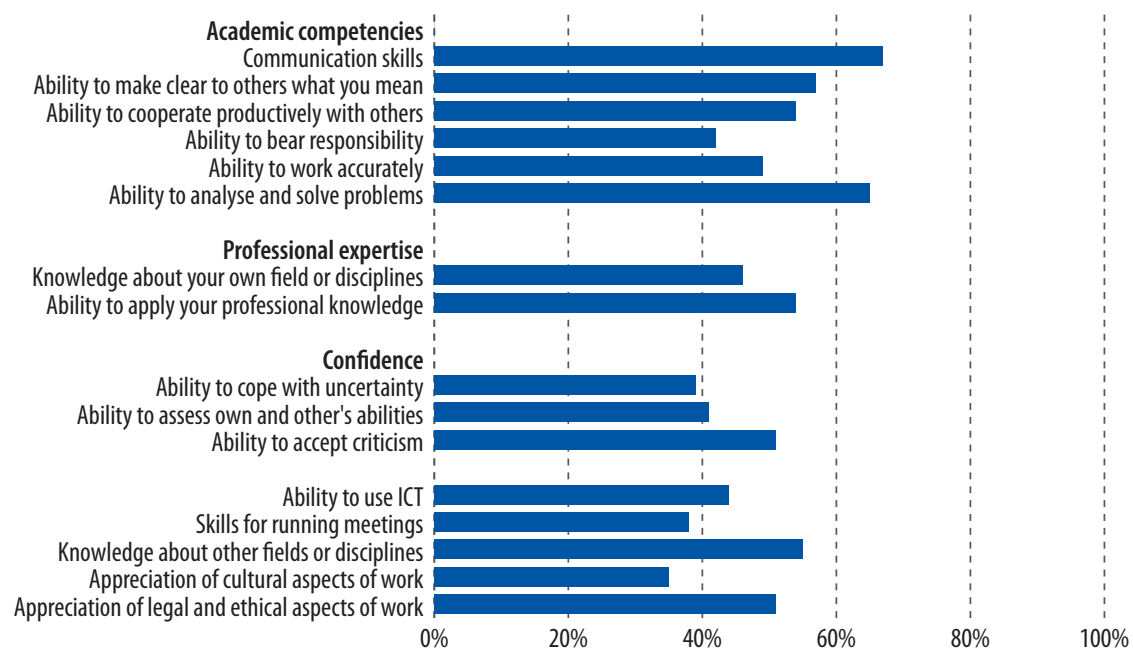

We can summarize the findings with respect to medicine graduates as follows: the skills related to professional expertise are more often required to a high or very high extent. Nevertheless, the medicine faculty does not have a strength in providing these skills. According to the medicine graduates, the strength of Maastricht University is providing communication skills. One of the greatest weaknesses of Maastricht University is the ability to bear responsibility. This is worrisome, as the ability to bear responsibility is mentioned by $96 \%$ of the medicine graduates as being required to a high or very high extent in their current jobs. 



\section{References}

Allen, J., Velden, R. van der, 2001, Educational mismatches versus skill mismatches: effects on wages, job satisfaction, and on-the-job search, Oxford Economic Papers, 53 (3), pp. 434452.

Allen, J., Velden, R. van der, 2012, Skills for the 21st century: Implications for education, $R O A-R M-2012 / 11$.

Australian National Training Authority, 2003, Defining generic skills at a glance, Adelaide: NCVER Ltd.

Becker, G.S., 1964. Human Capital: A Theoretical and Empirical Analysis with Special Reference to Education, New York: NBER.

Beller, M., 2011, Technologies in Large-Scale Assessments: New Directions, Challenges and Opportunities, presentation at International Large-Scale Assessment Conference, March 16-18, 2011 ETS , Princeton, NJ.

Bloom, B.S., 1956, Taxonomy of educational objectives: The classification of educational goals. Handbook 1: Cognitive domain, New York: McKay.

Coenen, J., C. Meng and R. Van der Velden, (2011, Schoolsucces van jongens en meisjes in het HAVO en VWO: waarom meisjes het beter doen, ROA-R-2011/2, Researchcentrum voor Onderwijs en Arbeidsmarkt, Maastricht.

Dupuy, A., 2004, Assignment and Substitution in the Labour Market, PhD thesis, Maastricht: ROA.

Ennis, C., 1987, A taxonomy of critical thinking dispositions and abilities, in Baron, J.B., Sternberg, R.J. (eds.) Teaching thinking skills, New York: Freeman, pp. 9-26.

Eurydice, 2002, Key Competencies: a developing concept in general compulsory education, retrieved from www.eurydice.org.

Eyraud, F., Marsden, D., Sylvestre, J.-J., 1990, Occupational and internal labour markets in Britain and France, International Labour Review, 129, pp. 501-517.

Gangl, M., 2001, European patterns of labour market entry. A dichotomy of occupationalized vs. non-occupationalized systems, European Societies, 3, pp. 471-494.

Green, F., 1998, The Value of Skills, Studies in Economics Series, Department of Economics, Kent OH: University of Kent.

Green, F., Ashton, D., Felstead, A., 2001, Estimating the determinants of supply of computing, problem-solving, communication, social, and teamworking skills, Oxford Economic Papers, Vol. 53 (3), pp. 406-33.

Halpern, D.F., 1998, Teaching critical thinking for transfer across domains. Dispositions, skills, structure training, and metacognitive monitoring, American Psychologist, 53, pp. 449-455.

Heijke, H., Koeslag, M., Velden, R. van der, 1998, Education, skills and wages, in Heijke, H., 
Borghans, L. (eds.), Towards a Transparent Labour Market for Educational Decisions, Aldershot, UK; Brookfield, VT and Sydney: Ashgate, pp. 253-271.

Heijke, H., Meng, C., Ramaekers, G., 2003, An investigation into the role of human capital competencies and their pay-off, International Journal of Manpower, Vol. 24 (7), pp. 743749.

Heijke, H., Meng, C., Ris, C., 2003, Fitting to the Job: the role of generic and vocational competencies in adjustment and performance, Labour Economics, 10 (2), pp. 215-229.

Heijke, H., Ramaekers, G., Ris, C., 2005, Do Business Administration Studies Offer Better Preparation for Supervisory Jobs than Traditional Economics Studies?, Education Economics, 13 (3), pp. 315-329.

Jolles, J., 2007, Neurocognitieve ontwikkeling en adolescentie: enkele implicaties voor het onderwijs, Onderwijsinnovatie, maart 2007, 30-32.

Jovanovic, B., 1979, Job matching and the theory of turnover. Journal of Political Economy, 87, pp. 1246-1260.

Latin, J., Carroll, J., Green, P., 2003, Analyzing multivariate data, London: Brooks/Cole Thomson Learning.

Lazaear, E.P., 2003, Firm-specific human capital: a skills-weight approach, IZA discussion paper no. 813, Bonn: IZA.

Lundvall, B., Johnson, B, 1994, The Learning Economy, Journal of Industrial Studies, 2, pp. $23-42$.

Marsden, D., 1990, Institutions and labour mobility. Occupational and internal labour markets in Britain, France, Italy and West Germany, in: Brunetta, R, Dell'Aringa, C., (eds.), Labour relations and economic performance, Houndsmills: Macmillian, pp. 414-438.

McCall, M.W., Lombardo, M.M., Morrison, A.M., 1988, The Lessons of Experience, How Successful Executives Develop on the Job, New York: The Free Press.

McIntosh, S., Vignoles, A., 2001, Measuring and assessing the impact of basic skills on labour market outcomes, Oxford Economic Papers, Vol. 53 (3), pp. 453-81.

Meng, C., 2006, Discipline-specific or Academic? Acquisition, Role and Value of Higher Education Competencies, Researchcentrum voor Onderwijs en Arbeidsmarkt, Maastricht.

Mincer, J., 1970, The distribution of labour incomes: a survey with special reference to the human capital approach, Journal of Economic Literature, 8 (1), pp.1-26.

Mincer, J., 1974, Schooling, Experience and Earnings, New York: Columbia University Press.

Mortensen, D., 1986, Job search and labour market analysis, in: Ashenfelter, O., Layard, R., (eds.) Handbook of Labour Economics, vol. 2, Amsterdam: North Holland, pp. 849-920.

Nunnually, J.C., 1978, Psychometric Theory, 2nd ed., New York: McGraw-Hill.

OECD (2010) The Nature of Learning: Using Research to Inspire Practice, OECD, Paris.

Payne, J., 2000, The unbearable lightness of skill: the changing meaning of skill in UK policy discourse and some implications for education and training, Journal of Education Policy, 15, pp. 353-369.

Petty, W., 1662, A Treatise on Taxes and Contributions, London.

Rey, B., 1996, Les compétences transversales en question. Collection Pédagogies. Paris: ESF éditeur.

Rychen, D.S., Salganik, L.H., 2003, A holistic model of competence, in: Rychen, D.S., Salganik, L.H., Key competencies for a successful life and a well-functioning society, Göttingen: 
Hogrefe \& Huber Publishers.

Say, J.-B., 1802, A Treatise on Political Economy, English translation of the 4th-5th ed., 1885 ed., Philadelphia: Grambo \& Co.

Schultz, T.W., 1961, Investment in human capital, The American Economic Review, 11, pp. $1-17$.

Shaughnessy, K.C., Levine, D.I. and Cappelli, P., 2001, Changes in managerial pay structures 1986-1992 and rising returns to skill, Oxford Economic Papers, Vol. 53 (3), pp. 482-507.

Slavin, R.E.,(2010, Co-operative learning: what makes group-work work? in OECD, The Nature of Learning: Using Research to Inspire Practice, OECD, Paris.

Smith, A., 1776, An Inquiry into the Nature and Causes of the Wealth of Nations, Glasgow edition, Oxford: Clarendon Press.

Stasz, C., 2001, Assessing skills for work: two perspectives, Oxford Economic Papers, 53 (3), pp. 385-405.

Sternberg, J. R., 2003, "What is an expert student", Educational Researcher, 32 (8), pp. 5-9.

Thurow, L.C., 1975, Education in Production, Journal of Political Economy, 78 (1), pp. 35-59.

Weel, B. ter, 2002, The computerization of the labour market, PhD thesis, Maastricht: Maastricht University.

Weinert, F. E., 2001, Concept of Competence: A Conceptual Clarification, in: Rychen, D. S., Salganik, L.H., Defining and selecting key competencies, Göttingen: Hogrefe \& Huber Publishers, pp. 43-65. 
